\title{
An Overview of Registered Clinical Trials on Glucosinolates and Human Health: The Current Situation
}

\author{
Mirko Marino, Daniela Martini, Samuele Venturi, Massimiliano Tucci, Marisa Porrini, \\ Patrizia Riso* and Cristian Del Bo'
}

Department of Food, Environmental and Nutritional Sciences (DeFENS), Università degli Studi di Milano, Milan, Italy

\section{OPEN ACCESS}

Edited by:

Elizabeth $H$. Jeffery,

University of Illinois at

Urbana-Champaign, United States

Reviewed by:

Teresa Oliviero,

Wageningen University and

Research, Netherlands

Maria Traka

Quadram Institute, United Kingdom

*Correspondence:

Patrizia Riso

patrizia.riso@unimi.it

Specialty section:

This article was submitted to

Clinical Nutrition,

a section of the journal

Frontiers in Nutrition

Received: 25 June 2021 Accepted: 24 September 2021

Published: 27 October 2021

Citation:

Marino $M$, Martini $D$, Venturi S, Tucci M, Porrini M, Riso P and Del

Bo' C (2021) An Overview of

Registered Clinical Trials on Glucosinolates and Human Health:

The Current Situation

Front. Nutr. 8:730906.

doi: 10.3389/fnut.2021.730906
Epidemiological studies suggest a potential role of glucosinolates (GSLs) and isothiocyanates on human health. However, evidence from intervention studies, due to heterogeneity in features of study design, duration, participants, food or food components administered, and outcomes analyzed, is still insufficient. The current review aims to provide an overview of the trials on GSLs and GSL-rich foods registered over the last 20 years with the intention to summarize the main topics and results, but also the existing gaps that still need to be covered. Studies were collected by using ClinicalTrials.gov and the International Standard Randomized Controlled Trial Number (ISRCTN) registry. A total of 87 registered trials were identified with which most of them were performed by using extracts or pure compounds $(n=60)$ while few were conducted with GSL-rich foods $(n=27)$. In detail, sulforaphane was the most investigated compound, while broccoli was the most frequent food tested in the trials. The majority of the studies assessed the health effects of GSLs focusing on outcomes related to cancer and cognitive function, even if the current findings are not univocal. Emerging topics also included the study of GSLs and gut microbiota interaction and impact on skin health. Further attention was also drawn to the bioavailability of GSLs and/or derivatives from foods, extracts, and single compounds by also considering the contribution of the different genetic polymorphisms. In conclusion, although considerable efforts have been made to study GSLs and GSL-rich foods, further studies are necessary to provide evidence-based research and to corroborate the findings obtained. The interindividual response due to genetic polymorphisms should be further investigated in order to explore the contribution to the overall beneficial effect.

Keywords: bioactives, Brassicaceae, sulfur compounds, clinical trials, human nutrition, health outcomes, food, food extracts

\section{INTRODUCTION}

Glucosinolates are a large group of plant secondary metabolites containing sulfur groups that are mainly found in cruciferous plants, such as broccoli, cauliflower, Brussel sprouts, cabbage, kale, watercress, and bok choy in which they play an important role in the defense mechanisms (1). From a chemical point of view, glucosinolates (GSLs) are composed of a thiohydroximate-O-sulfonate group linked to glucose, and an alkyl, aralkyl, and orindolyl side chain (2). The side-chain of the O-sulfate thiohydroximate moiety contributes to the diversity of natural GSLs, with more than 130 structures discovered so far (3-5). 
Glucosinolates are stable in plant cells, but when the plant is damaged such as in the case of cutting or chewing, they can be degraded by the enzyme myrosinase $(6,7)$. In detail, two different types of this enzyme exist: plant myrosinase, which coexists with GSLs in plants although physically segregated in vacuoles and thus not directly in contact with them, and bacterial myrosinase, which mainly acts in the colon (5). The thermal inactivation of myrosinase preserves some intact GSLs in cooked vegetables, and steaming was reported as the best cooking method to preserve them (8). The activity of myrosinase results in the production of a wide range of breakdown products, among which isothiocyanates (ITCs) are the most abundant (2).

The abundance of GSLs in Brassica vegetables makes these compounds of interest in the nutritional research field. Thus, the health benefits of GSLs and their breakdown products have been largely studied in the last decades in addition to considering the impact of several food-related (e.g., variety, agronomic factors, storage, and processing of the vegetables prior to consumption) and human-related (e.g., genetic factors, age, smoking habits) factors (9-16). These variables can affect the levels of GSLs ingested, their bioavailability and metabolism, and, in turn, their potential role on human health (17-19).

The study of the bioavailability of GSLs and derivatives is quite complex and, only recently, studies have focused their attention on understanding the absorption and metabolism of GSLs and breakdown products. The currently available data are derived mainly from the post-absorptive metabolism of ITCs reporting a urinary excretion of conjugated ITC metabolites following the intake of different cruciferous cooked vegetables (20-22). It has been documented that when Brassica vegetables are consumed without processing, plant myrosinase is able to hydrolyze GSLs in the proximal part of the gastrointestinal tract into different metabolites (e.g., ITCs, nitriles, oxazolidine-2thiones, and indole-3-carbinols), while when plants are thermally treated before consumption, myrosinase is inactivated and GSLs move into the colon where they are extensively hydrolyzed by bacteria and then absorbed and/or excreted (2). An in vivo study conducted in rats by using radiolabeled ITCs documented a rapid absorption (at about $3 \mathrm{~h}$ from the intake) of ITCs (23). Another study documented that the urinary concentration of native GSLs may reach up to $5 \%$ of the ingested dose followed by conjugation to glutathione at a hepatic level and then a urinary excretion in the form of mercapturic acid accounting for $12-80 \%$ of the ingested dose of ITCs (24). Regarding the impact of microbiota, few studies have been performed evaluating the contribution on GSLs metabolism and the impact of GSLs on microbiota composition. Data from in vitro studies reported the formation of amines and nitriles from GSLs $(23,25)$.

Regarding the contribution of GSLs and GSL-rich foods on human health, epidemiological evidence seems to support their role against the onset of non-communicable diseases, particularly those related but not limited to cancer (26-28). Cohort studies suggest an inverse association between the intake of broccoli and the risk of all cancers taken together (29) and an inverse association between consumption of Brassica vegetables and the risk of stomach cancer (30). A consistent inverse association between the risk of lung, stomach, colon, and rectal cancer and the high consumption of Brassica vegetables has been shown by case-control studies (31-33).

With the intention to investigate the main topics of research in the GSLs field, the aim of the present study was to perform an overview of the registered clinical trials in the last 20 years with the purpose of summarizing the main topics, results, and the existing gaps that still need to be covered. The information was obtained by examining public registries and available publications.

\section{MATERIALS AND METHODS}

\section{Search Strategy and Data Selection}

The study was conducted by searching clinical trials registered in "ClinicalTrials.gov" (34) and International Standard Randomized Controlled Trial Number (ISRCTN) registry (35). The search was firstly conducted on June 30, 2020, and updated on April 30, 2021, to identify additional studies. The search strategies involved the combination of different terms, using a syntax that was adapted for each registry. Below, the search strategy used for each registry is given.

- ClinicalTrials.gov: glucosinolates OR isothiocyanates OR glucoraphanin OR sulforaphane OR glucobrassicin OR 3indolylmethyl OR indol-3-carbinol OR thioglycosides OR thioglucosides OR progoitrin OR goitrin OR 1-5-vinyl-2thioöxazolidine OR sinagrin OR 4-methylsulfinylbutyl.

- ISRCTN Registry: (glucosinolates) OR (isothiocyanates) OR (glucoraphanin) OR (sulforaphane) OR (glucobrassicin) OR (3-indolylmethyl) OR (indol-3-carbinol) OR (thioglycosides) OR (thioglucosides) OR (progoitrin) OR (goitrin) OR (1-5-vinyl-2-thioöxazolidine) OR (sinagrin) OR (4-methylsulfinylbutyl).

The search strategy is summarized in Figure 1. Studies were considered eligible if they performed human intervention studies investigating the bioavailability of GSLs and/or their effects on any marker of human health. The only exclusion criteria adopted was the use of GSLs in combination with other nutrients or dietary bioactives or drugs in order to select specific studies focused on the effects of GSLs. No restrictions related to the country and the characteristics of the participants were applied.

A detailed list of eligibility criteria, developed by following the Population, Intervention, Comparison, Outcome, Study design (PICOS) format is provided in Table 1. Two independent reviewers ( $\mathrm{MM}$ and $\mathrm{CDB}$ ) conducted the study selection in the scientific databases and evaluated the eligibility of the clinical trials. Discrepancies between reviewers were solved through consultation with a third independent reviewer (DM) to achieve a consensus.

\section{Data Extraction}

Two reviewers (MM and $\mathrm{CDB}$ ) performed data extraction. A third reviewer (DM) checked the extracted information in order to ensure the accuracy of the data reported. For each study, the following information was collected: registration number, registration year, location, funding, participant information, study design, intervention, health condition, outcome measures, 


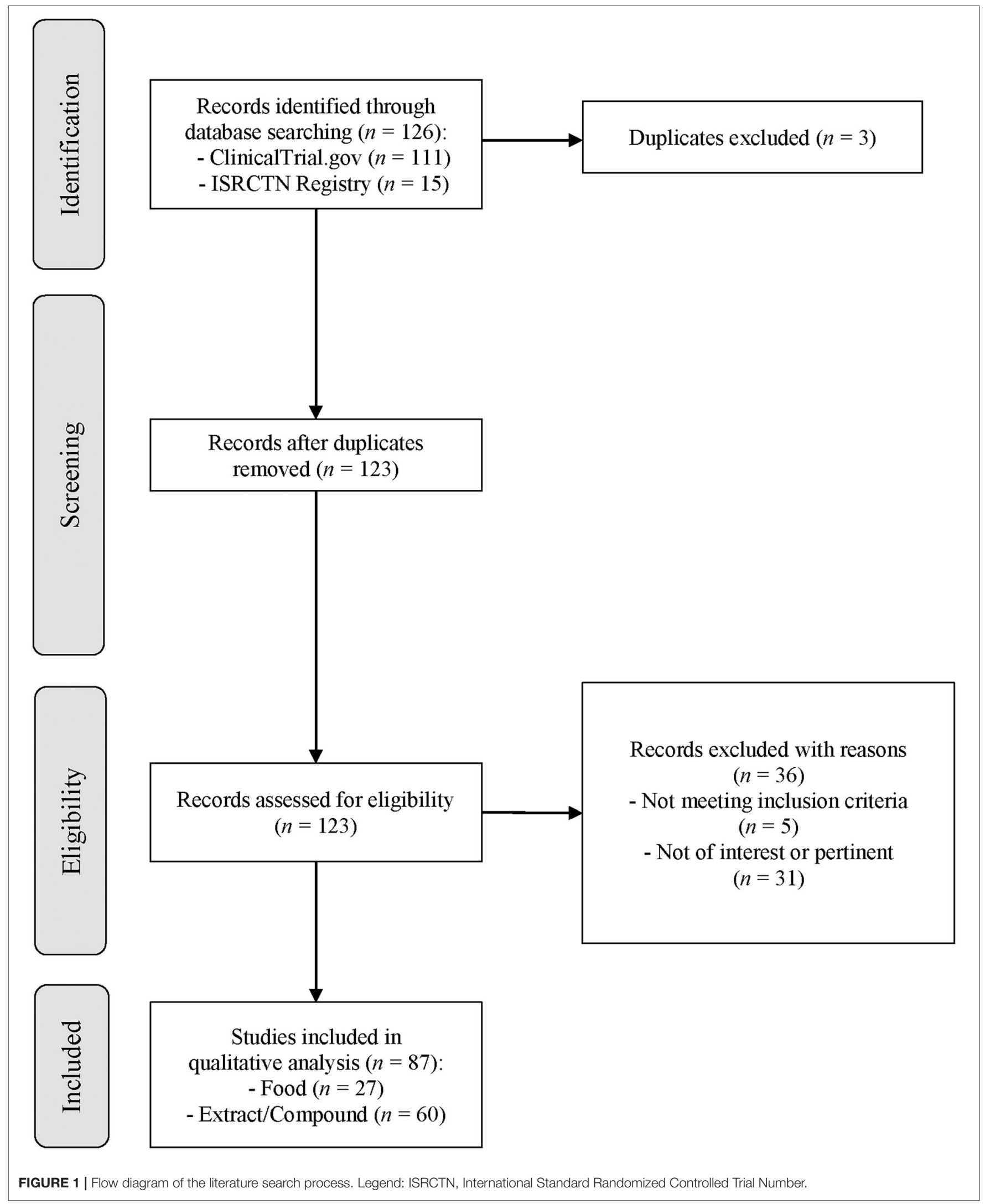


TABLE 1 | Population, intervention, comparison, outcome, study design (PICOS) criteria for trial selection cited.

\begin{tabular}{ll}
\hline Parameter & Criteria \\
\hline Population $(\mathrm{P})$ & $\begin{array}{l}\text { Healthy or diseased children, } \\
\text { adults and/or older adults } \\
\text { Food, extract or pure GSLs } \\
\text { tested alone. No other bioactive } \\
\text { compound or drug }\end{array}$ \\
Comparison $(\mathrm{C})$ & $\begin{array}{l}\text { Control group without GSLs } \\
\text { Ony effect on human health and } \\
\text { Outcome }(\mathrm{O})\end{array}$ \\
bioavailability \\
No restriction on study design
\end{tabular}

GSLs, glucosinolates.

and publications derived from the trials. Since no registered clinical trials were present before 2000, studies were classified into 4 main categories based on their start date (20002004, 2005-2009, 2010-2014, and 2015-2021). Within these different time intervals, all studies were then further divided into two sections: GSL-rich foods and GSL-rich extracts or single pure compounds. Regarding the study location, countries were classified as "low" (number of registered studies in that country <5), "medium" (5-10), and "high" (higher than 10) in accordance with previous investigations (36). Moreover, regarding the publications generated from the registered trials, the following data were extracted: name of first author, year of publication, country, registered trial number, study design, study population, duration of intervention, type of food or supplement, food characterization, primary outcome, and main findings.

\section{RESULTS}

\section{Study Selection}

The flow diagram of the literature search process for each registry is reported in Figure 1. The keywords utilized for the search string led to the identification of 126 clinical trials registered in ClinicalTrials.gov and the ISRCTN registry. In detail, 111 resulted from ClinicalTrials.gov, and 15 resulted from the ISRCTN registry. After the exclusion of 3 duplicates, 123 records were evaluated for eligibility and a total of 36 clinical trials were eliminated from the review. In particular, 31 studies were not pertinent with the focus of our study since they did not investigate the bioavailability or health effect of GSLs, and 5 clinical trials did not meet inclusion criteria due to the use of GSLs in combination with other compounds. Finally, 87 records were included in the qualitative analysis in order to collect the main characteristics of the clinical trials, as shown in Table 2. Overall, most of the studies were performed by using extracts or pure compounds while the main outcomes were related to the health effects followed by the bioavailability of GSLs and derivatives. The number of studies conducted on healthy subjects was similar to those carried out on patients, while chronic interventions were more frequent than the acute ones. As reported in Table 2, most of the registered clinical trials were developed in United States $(n=51)$, both for foods
TABLE 2 | The number of registered trials on GSL-rich foods and extracts or pure compounds, according to their characteristics.

\begin{tabular}{|c|c|c|}
\hline & Foods $(n=27)$ & $\begin{array}{l}\text { Extracts or Pure } \\
\text { Compounds ( } n= \\
60)\end{array}$ \\
\hline \multicolumn{3}{|l|}{ Goal } \\
\hline Health effects & 18 & 47 \\
\hline Bioavailability & 8 & 6 \\
\hline Both & 1 & 7 \\
\hline \multicolumn{3}{|l|}{ Duration } \\
\hline Acute & 8 & 2 \\
\hline Chronic & 18 & 55 \\
\hline Both & 1 & 3 \\
\hline \multicolumn{3}{|l|}{ Subjects } \\
\hline Healthy & 17 & 24 \\
\hline Subjects with risk factors & 3 & 2 \\
\hline Patients & 7 & 34 \\
\hline \multicolumn{3}{|l|}{ Primary outcome } \\
\hline Cardiovascular risk markers & 1 & 1 \\
\hline Glucose and insulin parameters & 0 & 2 \\
\hline Vascular and endothelial function & 0 & 2 \\
\hline Cognitive function & 0 & 15 \\
\hline Inflammation & 5 & 2 \\
\hline Gut microbiota & 2 & 0 \\
\hline Safety and tolerability & 1 & 5 \\
\hline Detoxification & 2 & 9 \\
\hline Blood GSLs concentration & 4 & 4 \\
\hline Urinary GSLs concentration & 7 & 8 \\
\hline Cancer & 4 & 11 \\
\hline Oxidative stress & 0 & 4 \\
\hline Skin health markers & 0 & 3 \\
\hline Other & 7 & 5 \\
\hline \multicolumn{3}{|l|}{ Location } \\
\hline United States of America & 14 & 37 \\
\hline United Kingdom & 10 & 6 \\
\hline China & 0 & 11 \\
\hline Sweden & 0 & 3 \\
\hline Spain & 2 & 0 \\
\hline Portugal & 1 & 0 \\
\hline Brazil & 0 & 1 \\
\hline Denmark & 0 & 1 \\
\hline Japan & 0 & 1 \\
\hline
\end{tabular}

GSLs, glucosinolates.

and extracts, and the main primary outcomes investigated were those related to cognitive function, cancer, and urinary GSL metabolites concentration.

\section{Trials on GSL-Rich Foods and Extracts/Pure Compounds}

Considering the whole period, from January 2000 to April 2021, registered clinical trials on GSLs that used extracts or pure compounds were $69 \%$ of the total number vs. $31 \%$ of studies that 
investigated the effect of GSL-rich foods (Figure 2A). Further, as shown in Figure 2B, the first clinical trial regarding a GSLrich food was registered in the time period 2010-2014, while a study on GSL-rich extract was already reported in the time interval 2000-2004 (Figure 2C). Moreover, in the time intervals considered, the number of studies performed on extracts or pure compounds was higher compared to those executed on GSL-rich foods. Additionally, these latter studies did not show a growing trend since during the last period (from 2015 to 2021), less studies were registered compared to 2010-2014. On the contrary, more than $50 \%$ (35 records out of 60) of registered clinical trials have been using GSLs' extracts or pure compounds between 2015 and 2021.

\section{Types of GSL-Rich Foods}

As reported in Figure 3A, the most studied GSL-rich food was represented by broccoli and broccoli sprouts, with 20 out of 27 clinical trials (74\%) registered in ClinicalTrials.gov and ISRCTN registry. In detail, 7 records were on whole broccoli, 5 on broccoli soup, 5 on broccoli sprouts, and 3 on broccoli sprout homogenate (BSH). Other GSL-rich foods considered were mustard (14.8\%), Brussel sprouts (7.4\%), watercress (7.4\%), and kale $(7.4 \%)$. Only one study investigated the effect of a highbrassica diet. Regarding the trend, the proportion of studies on broccoli compared to other foods was similar between the time periods, $68.7 \%$ (corresponding to 11 out of 16 studies) from 2010 to 2014, and $69.2 \%$ (9 out of 13 studies) between 2015 and 2021 (Figure 3B).

\section{Types of GSL-Rich Extracts}

In a similar manner to the intervention studies on GSL-rich foods, broccoli extract was the most studied, accounting for $83.3 \%$ of the registered trials (Figure 4A). Moreover, clinical trials on broccoli extracts observed a constant increase over the years, ranging from 6 registrations between 2005 and 2009 to 11 records between 2015 and 2021 (Figure 4B). During the last time interval (from 2015 to 2021), other food extracts consisting of broccoli seeds (13.3\%) and watercress (3.3\%) were used.

\section{Types of Pure GSLs}

Among the 33 intervention studies that were conducted by testing pure compounds, 29 trials $(87.9 \%)$ were on sulforaphane (SFN), 3 (9.1\%) on phenethyl isothiocyanate (PEITC), and only $1(3 \%)$ on glucoraphanin (GR) (Figure 5A). Most of the clinical trials which used SFN as extract were registered during the last time period (22 out of 29), showing a growing trend (Figure 5B). From 2000 up to 2004, only 1 study has been recorded, and it was on PEITC. On the other hand, the same compound did not observe an increasing interest over the years, maintaining 1 study for each time period and no records during the last time interval, from 2015 until today.

\section{Characteristics of Subjects}

In relation to the characteristics of the participants (Figure 6), trials on GSLs were conducted both on healthy subjects ( $n=41$ studies, $47.1 \%)$ and subjects with diseases such as cancer, Alzheimer's disease, diabetes mellitus, depressive disorder, and autism spectrum disorder $(n=41$ studies, $47.1 \%)$. While, only five (5.7\%) clinical trials enrolled subjects with cardiovascular risk factors, such as overweight, prehypertension, hypercholesterolemia, and smokers. The enrollment of participants with diseases was more frequent in clinical trials that provided extracts than studies on GSLrich foods (34 and 7 studies, respectively). On the contrary, interventions with foods involved mainly healthy subjects than trials on GSL-rich extracts (63 and 40\%, respectively). Regarding the age of participants, $46(53.5 \%)$ registered clinical trials included both adults and older subjects, $32(37.2 \%)$ studies included only adults, 6 (7\%) studies focused on children, while 2 (2.3\%) studies included only older individuals.

\section{Principal Purposes of the Registered Trials}

The main objectives of the registered clinical trials are reported in Figure 7A. Most of the trials were focused on the evaluation of the health effects of extracts and foods, followed by studies on bioavailability. In particular, 65 clinical trials (18 on foods and 47 on extracts) were concerned with the health effects, 14 (8 on GSL-rich foods and 6 on extracts) were focused on bioavailability, while 8 ( 1 on GSL-rich foods and 7 on extracts) evaluated both. As depicted in Figure 7B, intervention studies having as an outcome the evaluation of the health effects increased over time, moving from 4 registered trials in the period 2005-2009, until 35 studies in the period 2015-2021. Similarly, studies on bioavailability increased throughout the time periods considered, starting from only 1 registered between 2005 and 2009 until 9 studied recorded from 2015 to 2021 . While studies investigating both health effects and bioavailability remained limited and stable across the time intervals, with an average of 2 registrations every 5 years.

The primary outcomes assessed in the registered trials are shown in Figure 8A. Markers of cognitive function, cancer, and bioavailability were the most analyzed. In detail, they were reported in 45 records out of 87 ( 15 studies for each category), accounting for $51.7 \%$ of all studies, followed by the studies focused on the activity of detoxification enzymes (11 trials; $12.6 \%$ ). A similar number of studies were devoted to assessing GSL blood concentration $(n=8)$ and the role of foods and extracts on inflammation $(n=7)$ and safety/tolerability markers $(n=6)$. Other primary outcomes analyzed within the trials included: oxidative stress $(n=4)$, cardiovascular risk $(n=4)$, skin health $(n=3)$, gut microbiota $(n=2)$, and glucose/insulin parameters $(n=2)$. Among the group "Other," reported in Figure 8A are included primary outcomes investigated only in one record out of the 87 assessed and some of them are the effect of GSLs on osteoarthritis, hormone metabolism, energy expenditure, and drug interaction (Figure 8A). This last category of outcomes "Other" observed a growing trend over the years, from 0 records in the period 2000-2004, to 1,3 , and 8 in the periods 2005-2009, 2010-2014, and 2015-2021, respectively (Figure 8B). Another category of outcomes that received greater attention only in recent years was cognitive function. During the period 2015-2021, 13 studies were registered while only 2 were found from 2010 to 2014. Similarly, the studies on bioavailability registered an increasing trend. In particular, the assessment of GSLs and their metabolites in urine and blood moved from 1 
A

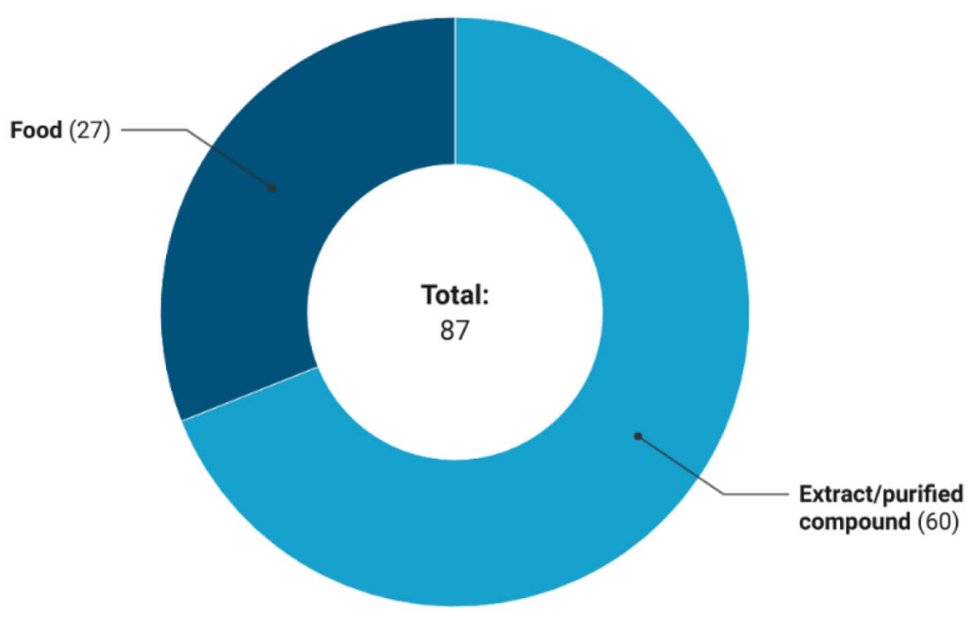

B

Number of food studies on glucosinolate-rich foods

2000-2004 0

2005-2009 0

2010-2014 15

2015-2021 12

C

Number of food studies on glucosinolate-rich extracts/pure compounds
2000-2004
1
2005-2009
2010-2014
2015-2021
7
17
35

FIGURE 2 | Number (A) and trend of registered trials on GSL-rich foods (B), and extracts or pure compounds (C).

trial recorded in 2000-2004, to 3, 7, and 12 studies registered in the period 2005-2009, 2010-2014, and 2015-2021, respectively. Regarding outcomes related to the detoxification enzyme activity, cancer risk, inflammation, safety, and tolerability, the number of studies on these topics registered a decrease in the last period (2015-2021) compared to the previous one (2010-2014), moving from a total of 20 records to 11 (Figure 8B).

\section{Other Characteristics of the Registered Trials}

The main countries in which clinical trials were conducted are depicted in Figure 9. The highest number of registered studies on foods and extracts was observed in the USA (51 clinical trials: 37 on extracts and 14 on GSL-rich foods). UK and China were the countries with the highest number of studies on GSL-rich foods 
A

Broccoli Broccoli soup Broccoli sprout Broccoli sprout homogenate

Brussel sprout

High brassica diet Watercress juice Mustard Mustard seed $\square$ Kale

2000-2021

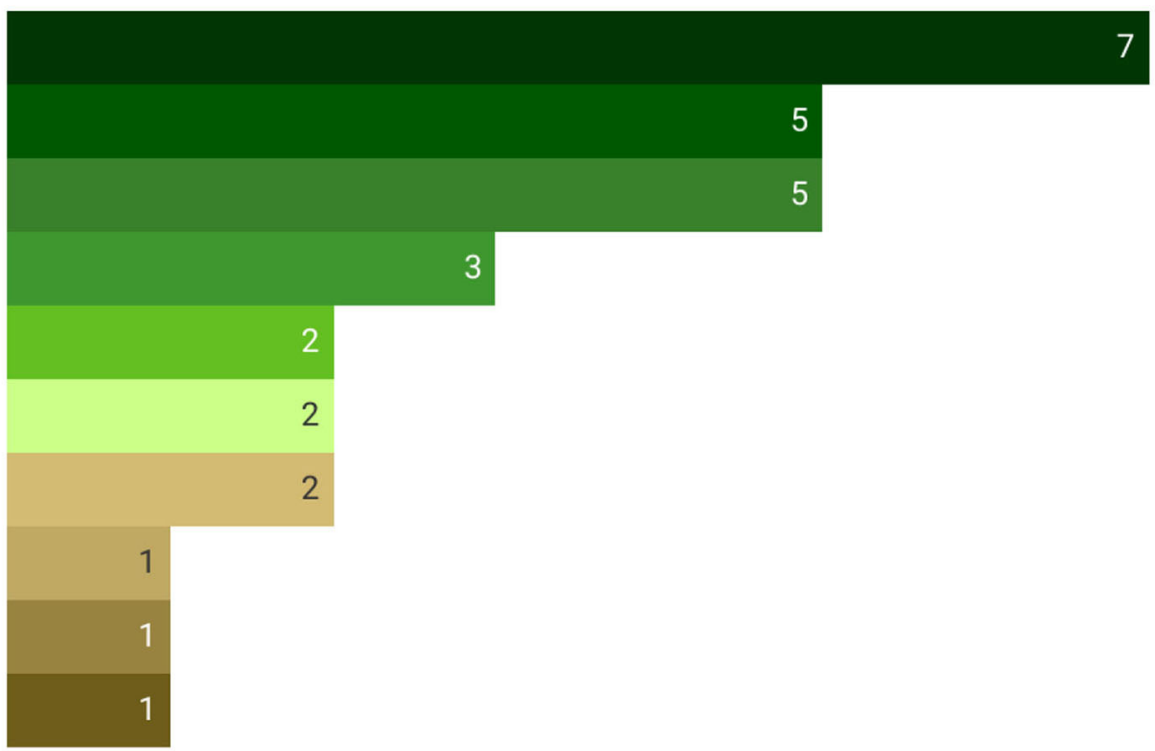

B

Broccoli $\square$ Broccoli soup $\square$ Broccoli sprout $\square$ Broccoli sprout homogenate Brussel sprout High brassica diet Watercress juice Mustard Mustard seed $\square$ Kale

$\begin{array}{ccccccccccc}2000-2004 & 0 & 0 & 0 & 0 & 0 & 0 & 0 & 0 & 0 & 0 \\ 2005-2009 & 0 & 0 & 0 & 0 & 0 & 0 & 0 & 0 & 0 & 0 \\ 2010-2014 & 4 & 1 & 3 & 3 & 1 & 1 & 2 & 1 & 0 & 0 \\ 2015-2020 & 3 & 4 & 2 & 0 & 1 & 1 & 0 & 0 & 1 & 1\end{array}$

FIGURE 3 | Main glucosinolates (GSL)-rich foods (A) used in clinical trials and their trend (B). The total count of GSL-rich foods is higher than the total count of the corresponding studies since in some studies more than one food has been provided to the participants.

(16 trials: 6 on extracts and 10 on foods) and extracts (11 trials: 11 on extracts and 0 on foods), respectively. Other countries included: Sweden $(n=3)$, Spain $(n=2)$, Brazil $(n=1)$, Denmark $(n=1)$, Japan $(n=1)$, and Portugal $(n=1)$.

Regarding the type of funding, 65 studies $(74.7 \%$ of the total number) received government funding, 48 were on extracts or pure compounds, and 17 were on GSL-rich foods. Private funding was allocated to 20 clinical trials, 9 on foods and 11 on extracts, while only 2 studies were funded with both government and public funding.

\section{Characteristics and Results of the Publications Derived From Registered Trials}

Among the 87 registered trials, 28 publications were directly associated with ClinicalTrials.gov and ISRCTN registry. The 


\section{A}

\section{Broccoli sprout Broccoli seed Watercress}

\section{0-2021}

\section{Broccoli sprout Broccoli seed Watercress}

\section{$2000-2004 \quad 0$ \\ 0 \\ 0 \\ 8 \\ 11 \\ 0

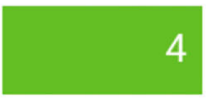 \\ 0 \\ 0 \\ 0 \\ 1 \\ FIGURE 4 | Main GSL-rich extracts (A) used in clinical trials and their trend (B). The total count of GSL-rich extracts is higher than the total count of the} corresponding studies since in some studies more than one extract has been provided to the participants.

main characteristics and results of the 28 publications are reported in Tables 3, 4. Out of these 28 studies, 16 were performed on GSL-rich foods (Table 3) while 12 were on GSLrich extracts and/or pure compounds (Table 4).

\section{Characteristics and Results of the Studies Performed on GSL-Rich Foods}

The main characteristics of the studies performed on GSL-rich foods are reported in Table 3. Most of the studies focused on the bioavailability of GSLs and derivatives followed by those evaluating the effects on human health. Regarding bioavailability, five studies tested the absorption and metabolism of GSLs from broccoli and broccoli sprouts. One study foresaw the administration of a single portion of broccoli (one serving or a dose equivalent to 200-300 g of raw product), while four studies a medium-long term intervention (range 14-64 days) and included the administration of two portions/day (at about $100 \mathrm{~g}$ each of broccoli) or three portions/week $(300 \mathrm{ml}$ each of broccoli soup). The main target tissues were plasma and urine followed by prostate tissue. Four out of five studies on GSLrich foods were already published. Charron et al. (46) aimed to assess the change in GSL-metabolites measured in plasma and urine after the acute consumption of $100 \mathrm{~g}$ of broccoli and $10 \mathrm{~g}$ of daikon radish (providing about $100 \mu \mathrm{mol}$ ITCs). The authors found that the absorption and metabolism of GSLs from cooked broccoli were widely affected by the body mass index (BMI) of the subjects. In particular, subjects with high BMI (i.e., higher than $26 \mathrm{~kg} / \mathrm{m}^{2}$ ) had elevated levels of plasma and urinary metabolites and a delayed maximal plasma metabolite peak compared to those with low BMI (i.e., lower than $26 \mathrm{~kg} / \mathrm{m}^{2}$ ). The authors attributed this BMI-associated response to the different gut transit times and/or differences in gut microbiota 


\section{A}

\section{Sulforaphane Phenethyl isothiocyanate Glucoraphanin}

\section{0-2021}

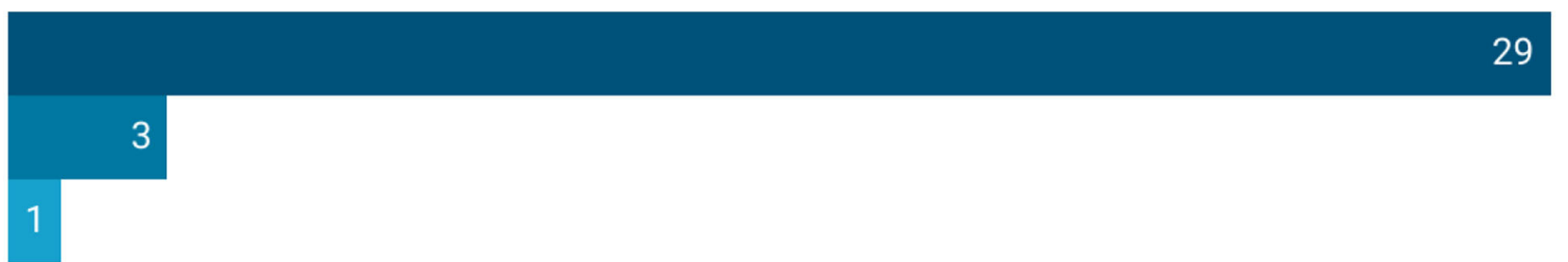

B

\section{Sulforaphane Phenethyl isothiocyanate Glucoraphanin}

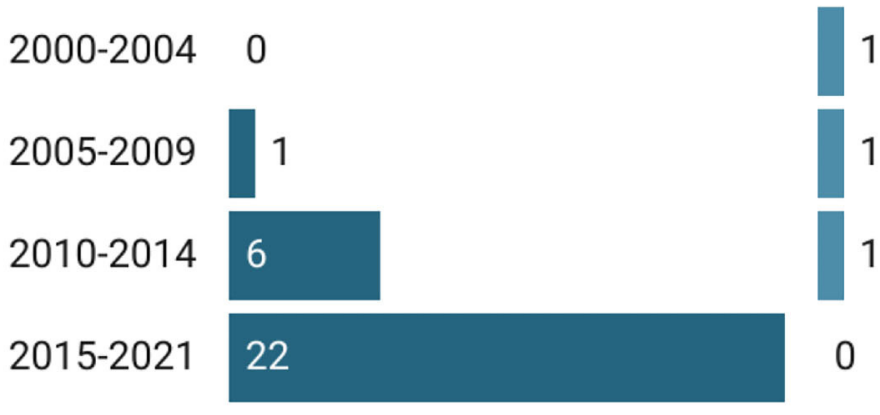

1

1

1

0
0

0

1

0

FIGURE 5 | Main pure GSLs used in clinical trials (A) and their trend (B). The total count of pure GSLs is higher than the total count of the corresponding studies since in some studies more than one GSL has been provided to the participants.

composition. Conversely, the same authors previously reported that subjects with high BMI showed higher plasma AUC and urinary excretion rates of total GSL and GSL-metabolites (erucin, SFN, and SFN-metabolites) following the consumption of control diet compared to the broccoli diet. Whereas, subjects with low BMI reported higher plasma AUC and urinary excretion rates following the administration of a broccoli diet ( $200 \mathrm{~g}$ of cooked broccoli and $20 \mathrm{~g}$ of raw daikon radish, providing $97.5 \mu \mathrm{mol}$ of GR and $5.8 \mu \mathrm{mol}$ of glucoerucin) for 15 days and followed by two single administrations the days after. In detail, the plasma AUC of total metabolites of low BMI subjects was 17\% higher during the broccoli diet compared to the control diet (46). Sivapalan et al. (17) evaluated the absorption and excretion of GR, glucoerucin, and metabolites in plasma and urine of healthy subjects after the acute intake of 3 soups ( $300 \mathrm{~g}$ each) made from different broccoli genotypes (range of GR $84-452 \mu \mathrm{mol}$ ). The authors reported that the absorption and excretion of GSLs and metabolites were dependent on broccoli genotype and higher for the cultivar rich in GSLs. Finally, Coode-Bate and coworkers (49) reported no detectable levels of GSLs and derivatives in prostate biopsy tissues after 4-week consumption of three $300 \mathrm{ml}$ portions/week of a broccoli soup (providing at about $280 \mu \mathrm{mol}$ of GR and 1,513 $\mu \mathrm{mol}$ of (+)-S-methyl cysteine sulfoxide). On the contrary, the authors documented high levels of the sulfate metabolite (+)-S-methyl cysteine sulfoxide in the same target tissue and urine.

The main food sources used for studying the effects on human health were broccoli and broccoli sprout. These were tested both in healthy subjects and in those with risk factors. Only few studies were performed on subjects with prostate cancer. The duration of the intervention varied from a few days to until 10 weeks, while the dose of food was in the range of 


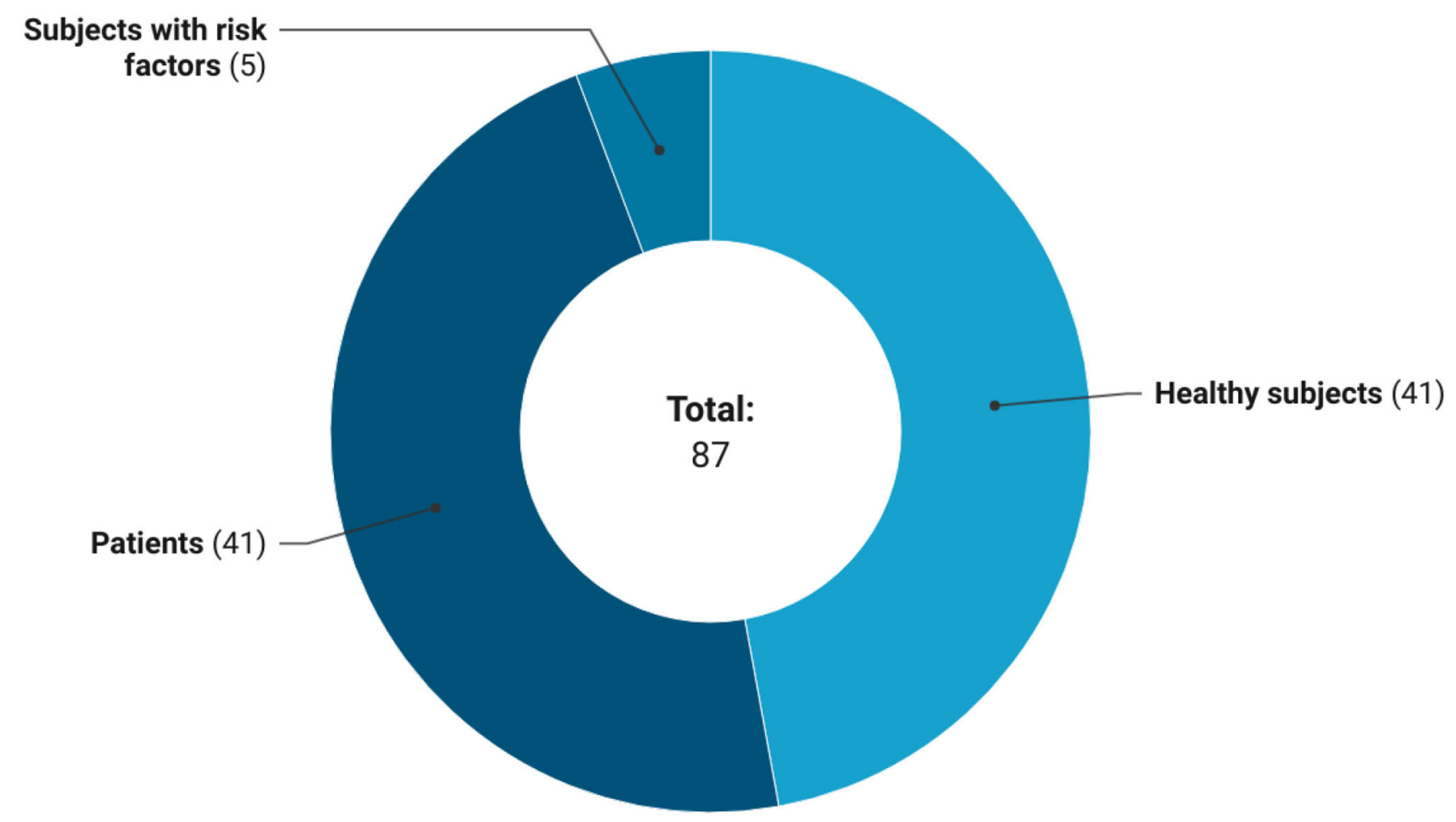

FIGURE 6 | Health status of subjects included in the registered clinical trials.

30-200 g per day. The main markers considered included those related to inflammation, detoxification (mainly gene expression or enzymatic activity), and cancer risk analyzed mainly in the blood, targeted cells (peripheral blood mononuclear cells), or tissue (e.g., prostate). Noah et al. (39) showed that the ingestion of $200 \mathrm{~g}$ of $\mathrm{BSH}$ for 4 days was able to significantly reduce virus-induced markers of inflammation, such as IL-6, in smoker subjects compared to the placebo. Similarly, López-Chillón et al. (47) observed a significant decrease in plasma levels of IL-6 and C-reactive protein following 10-week consumption of broccoli sprouts (30 g/day) in healthy overweight subjects. Regarding the biomarkers of oxidative stress, Nguyen and coworkers (45) found a significant reduction of reactive oxygen species (ROS) and p38 MAP kinase in healthy non-smoker subjects following ingestion of $200 \mathrm{~g}$ of $\mathrm{BSH}$ compared to the placebo (alfalfa sprout homogenates). Doss et al. (40) demonstrated that the treatment for 21 days with $150 \mathrm{~g}$ of $\mathrm{BSH}$ in adults with sickle cell disease determined the activation of nuclear factor erythroid 2-related factor 2 (Nrf2) in erythroid progenitors and significantly increased the expression of Nrf2 targets such as heme oxygenase 1 (HO-1), NAD $(\mathrm{P}) \mathrm{H}$ Quinone Dehydrogenase 1 (NQO1), and hemoglobin subunit gamma 1 (HBG1), restoring oxidative capacity. On the other hand, Sudini et al. (43) did not find any difference in transcript levels of Nrf2 target antioxidant genes HO-1, NQO1, glutamate cysteine ligase catalytic subunit (GCLC), and glutamate cysteine ligase modifier subunit (GCLM) in nasal epithelial cells and peripheral blood mononuclear cells (PBMCs) between the treatment with $100 \mathrm{~g}$ broccoli sprouts for three consecutive days and the placebo (alfalfa sprouts) among adults with asthma and allergic sensitization.

\section{Characteristics and Results of the Studies Performed on GSL-Rich Extracts/Pure Compounds}

The main characteristics of the studies performed on GSLrich extracts/pure compounds are reported in Table 4. The bioavailability of GSLs and derivatives obtained from extracts and/or pure components have been evaluated in 13 studies. The main compounds tested were broccoli sprout extracts and SFN, analyzed in plasma and urine and in line with the studies performed on GSL-rich foods reported above. Some of the trials combined the study of bioavailability with that of the health effect. The dose administered was variable depending on the extract/compound tested (from 8 up to $600 \mu \mathrm{mol}$ ) and mainly in the form of pills or capsules. The duration of the studies was varying between one or few days up to 12 weeks depending on the aim of the research. The markers associated with the bioavailability included the dosage of the native GSL, derivatives (e.g., SFN), or metabolic products analyzed mainly in plasma and urine while those related to human health included markers directly and/or indirectly associated with prostate cancer, cognitive function, and cardiovascular health including inflammatory and antioxidant markers detected in plasma or target tissues. Only half of the studies have already been published. Regarding the bioavailability, Chen et al. (48) documented an increase in urinary SFN metabolites following the administration for 10 days of three different 
A

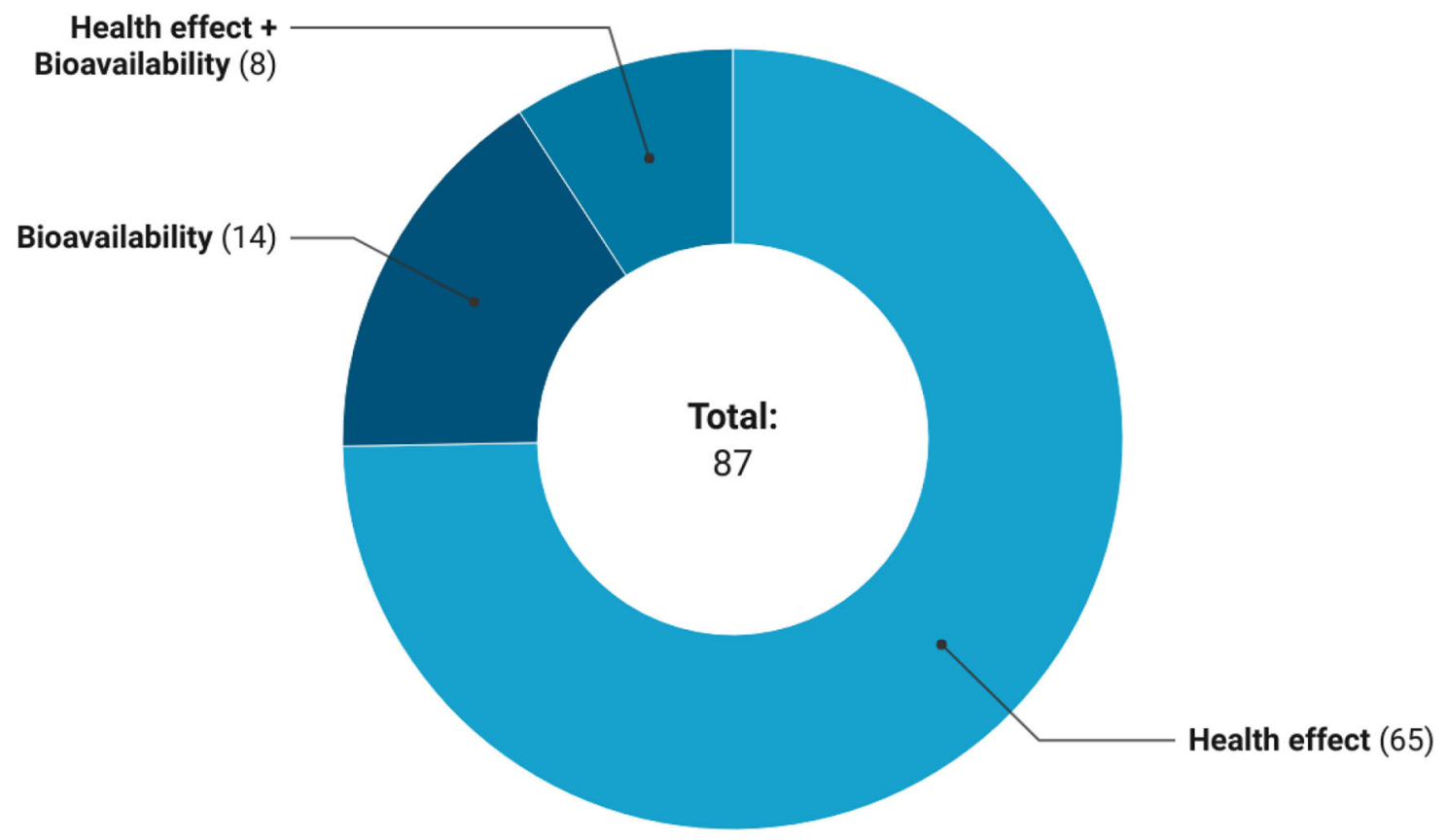

B

\begin{tabular}{|l|l|l|l|}
\hline $2000-2004$ & $2010-2014$ & $2015-2021$
\end{tabular}

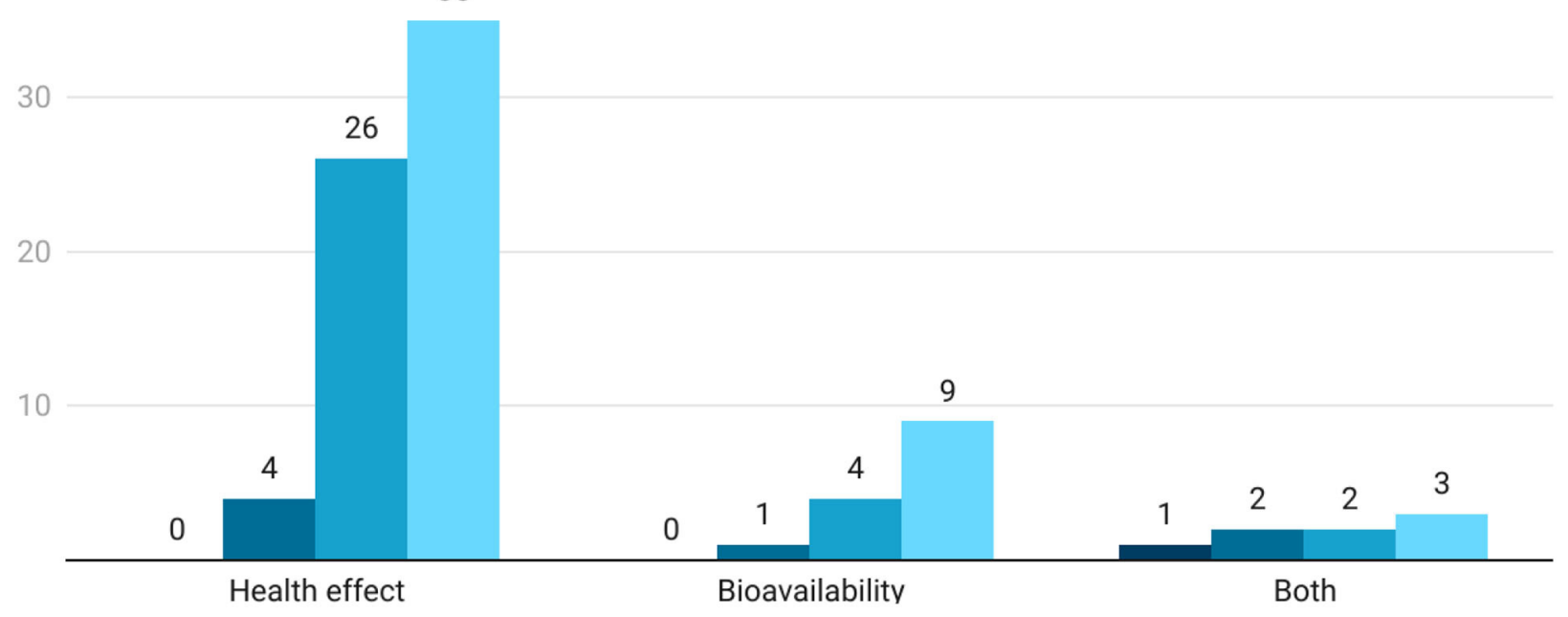

FIGURE 7 | Number (A) and trend (B) of studies that assess bioavailability, health effect, and both bioavailability and health effect of GSLs. 
A

Cognitive function Cancer Urine concentration of glucosinolates Detoxication enzyme activity Blood concentration of glucosinolates Inflammation Safety and tolerability Oxidative stress Cardiovascular Skin health Glucose and insulin parameters Gut microbiota Other

\section{Number of studies during 2000-2021}

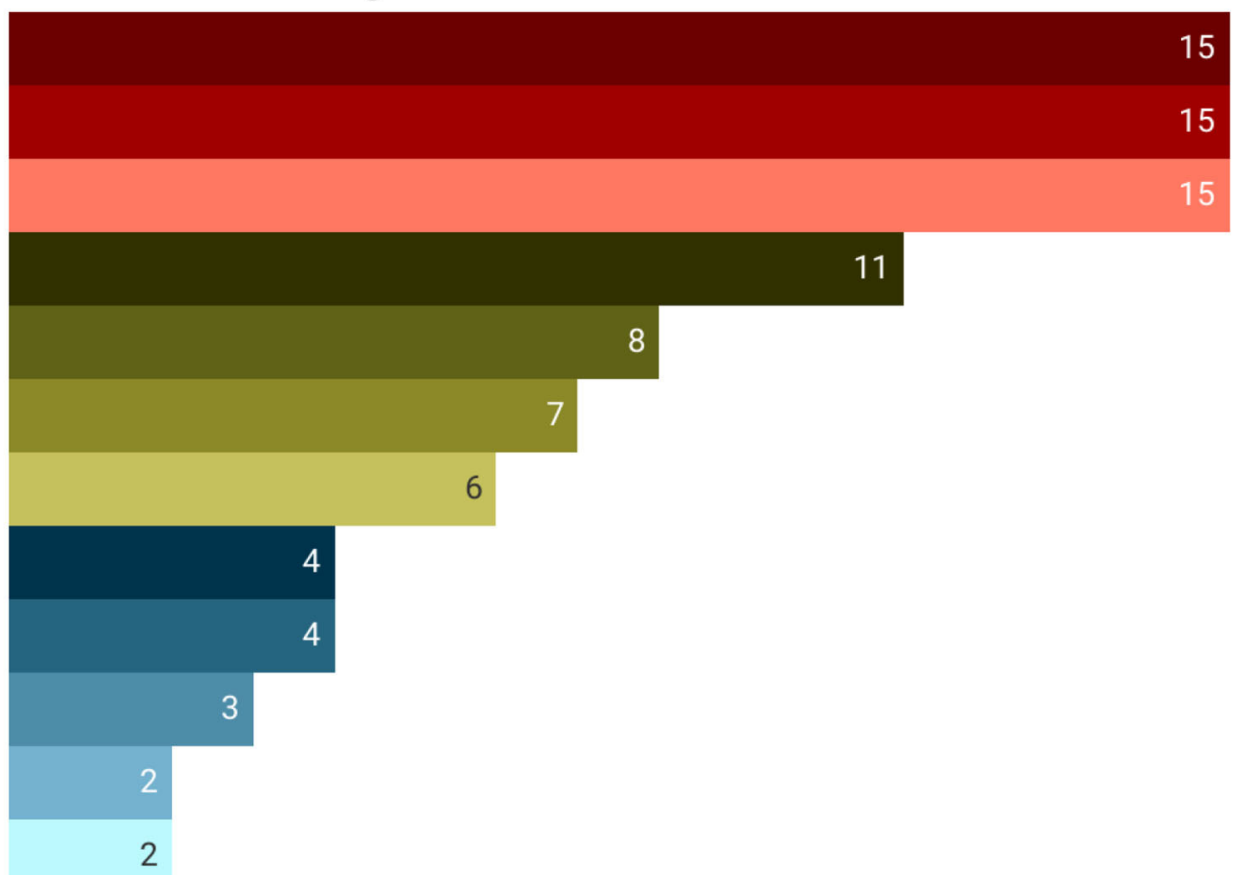

B

Cognitive function Cancer Urine concentration of glucosinolates Detoxication enzyme activity Blood concentration of glucosinolates Inflammation Safety and tolerability $\square$ Oxidative stress Cardiovascular Skin health Glucose and insulin parameters Gut microbiota Other

\begin{tabular}{|c|c|c|c|c|c|c|c|c|c|c|c|c|c|}
\hline $2000-2004$ & 0 & 1 & 0 & 0 & 1 & 0 & 1 & 0 & 0 & 0 & 0 & 0 & 0 \\
\hline 2005-2009 & 0 & 3 & 3 & 0 & 0 & 1 & 0 & 0 & 1 & 0 & 0 & 0 & 1 \\
\hline 2010-2014 & 2 & 6 & 4 & 6 & 3 & 4 & 4 & 2 & 1 & 0 & 0 & 1 & 3 \\
\hline $2015-2021$ & 13 & 5 & 8 & 5 & 4 & 2 & 1 & 2 & 2 & 3 & 2 & 1 & 8 \\
\hline
\end{tabular}

FIGURE 8 | Primary outcomes (A) and their trend (B) assessed during clinical trials on GSLs. 
$\mathbf{A}$
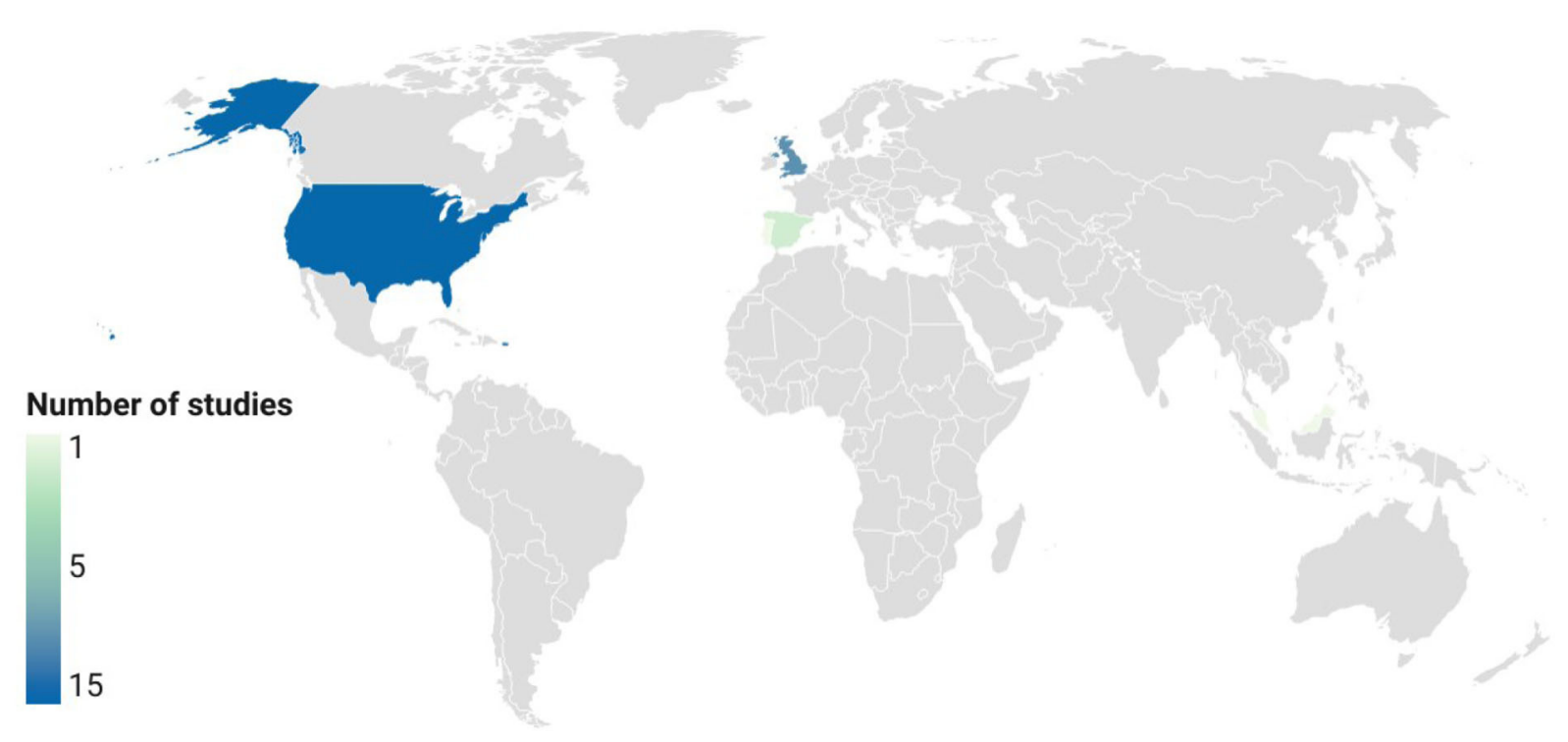

B

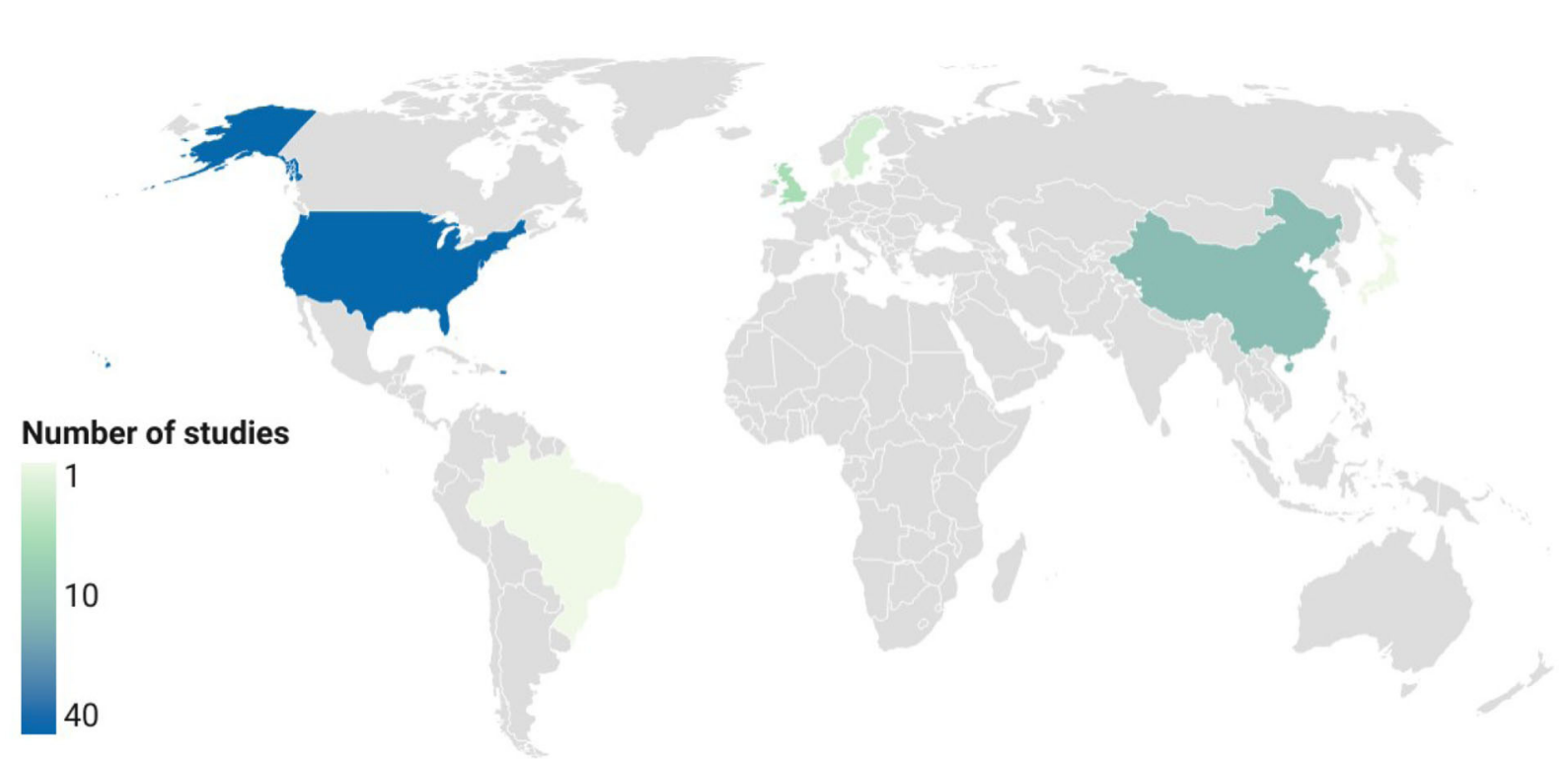

FIGURE 9 | Countries with the highest number of registered studies on GSL-rich foods (A) and extracts (B). "Low": <5 registered trials; "medium": 5-10 registered trials; "high": >10 registered trials. Locations not reporting clinical trials on GSLs are colored in gray.

broccoli sprout beverages $(100 \mathrm{ml}$ each) containing different concentrations of GR (range 120-600 $\mu \mathrm{mol}$ ) and SFN (range 8-40 $\mu \mathrm{mol})$. In addition, the authors found a significant increase in benzene mercapturic acids in the urine of the group of subjects consuming the high-dose beverage. In another study (53), a 2-week intervention with $250 \mathrm{mg} /$ day of a broccoli seed extract containing GR (224 mg/day) induced a significant change in total urinary SFN and individual SFN metabolites in a group of women scheduled for breast biopsy. Recently, Zhang et al. (61) reported a significant increase in total and individual SFN metabolites in urine and plasma following 2-week consumption of 2 capsules/day (providing 200 
TABLE 3 | Characteristics and findings of publications associated with registered trials on GSL-rich foods.

\begin{tabular}{|c|c|c|c|c|c|c|c|}
\hline $\begin{array}{l}\text { Reference, } \\
\text { country, } \\
\text { registry ID }\end{array}$ & Study design & Study population & $\begin{array}{l}\text { Duration of } \\
\text { intervention }\end{array}$ & $\begin{array}{l}\text { Food or supplement } \\
\text { intervention }\end{array}$ & $\begin{array}{l}\text { Control or } \\
\text { placebo } \\
\text { intervention }\end{array}$ & $\begin{array}{l}\text { Primary outcome and } \\
\text { other variable outcomes }\end{array}$ & Main findings \\
\hline $\begin{array}{l}\text { Christiansen et al. } \\
\text { (37), Denmark, } \\
\text { NCT00252018 }\end{array}$ & $\begin{array}{l}\text { Randomized, } \\
\text { parallel, controlled, } \\
\text { single-blind }\end{array}$ & $\begin{array}{l}n=41 \text { hypertensive subjects, non-smoker and } \\
\text { without diabetes or hypercholesterolemia } \\
\text { Control group: } n=20 \text { (15F, } 5 \mathrm{M}) \text { age } 54 \pm 10 \mathrm{y} \\
\text { BMl } 26.2 \pm 3.2 \mathrm{~kg} / \mathrm{m}^{2} \\
\text { Intervention group: } n=21 \text { (10F, } 11 \mathrm{M}) \text { age } 58 \pm \\
9 \mathrm{y}, \mathrm{BMI} 29.1 \pm 6.6 \mathrm{~kg} / \mathrm{m}^{2}\end{array}$ & 4 weeks & $\begin{array}{l}10 \mathrm{~g} \text { dried broccoli sprouts } \\
\text { daily }(25.9 \pm 8.5 \mu \mathrm{mol} / \mathrm{g} \\
\text { dry-weight GR; } \\
48.5 \pm 14.2 \mu \mathrm{mol} / \mathrm{g} \\
\text { dry-weight total GSL) }\end{array}$ & Habitual diet & $\begin{array}{l}\text { FMD (primary outcome), } \\
\text { BP, HDL-C, LDL-C }\end{array}$ & $\leftrightarrow$ \\
\hline $\begin{array}{l}\text { Armah et al. (38), } \\
\text { UK, } \\
\text { NCT01114399 }\end{array}$ & $\begin{array}{l}\text { Randomized, } \\
\text { 3-arm parallel, } \\
\text { controlled }\end{array}$ & $\begin{array}{l}n=48 \text { CVD risk subjects } \\
\text { Control group: } n=10(5 \mathrm{M}) \text { age } 62.0 \pm 2.12 \mathrm{y} \\
\text { BMl } 25.4 \pm 2.79 \mathrm{~kg} / \mathrm{m}^{2} ;(5 \mathrm{~F}) \text { age } 61.4 \pm 2.51 \\
\text { y, BMl } 26.4 \pm 3.73 \mathrm{~kg} / \mathrm{m}^{2} \\
\text { HG broccoli group: } n=19(10 \mathrm{M}) \text { age } 59.8 \pm \\
7.28 \mathrm{y}, \mathrm{BMI} 25.8 \pm 2.99 \mathrm{~kg} / \mathrm{m}^{2}, 1 \mathrm{smoker} ;(9 \mathrm{~F}) \\
\text { age } 63.8 \pm 7.92 \mathrm{y}, \mathrm{BMl} 25.1 \pm 3.73 \mathrm{~kg} / \mathrm{m}^{2} \\
\text { Standard broccoli group: } n=19(9 \mathrm{M}) \text { age } 57.3 \\
\pm 5.83 \mathrm{y}, \mathrm{BMl} 24.6 \pm 3.17 \mathrm{~kg} / \mathrm{m}^{2}, 1 \text { smoker; } \\
(10 \mathrm{~F}) \text { age } 60.8 \pm 5.31 \mathrm{y}, \mathrm{BMl} 26.0 \pm 3.20 \\
\mathrm{~kg} / \mathrm{m}^{2}, 1 \text { smoker }\end{array}$ & 12 weeks & $\begin{array}{l}\text { High-GR broccoli group: } \\
400 \mathrm{~g} \text { High-GR broccoli } \\
\text { every week ( } 21.6 \pm 1.60 \\
\mu \mathrm{mol} / \mathrm{g} \text { dry-weight GR and } \\
4.5 \pm 0.34 \mu \mathrm{mol} / \mathrm{g} \\
\text { dry-weight glucoiberin) } \\
\text { Standard broccoli group: } \\
400 \mathrm{~g} \text { of a standard } \\
\text { broccoli cultivar every week } \\
(6.9 \pm 0.44 \mu \mathrm{mol} / \mathrm{g} \\
\text { dry-weight } \mathrm{GR} \text { and } \\
0.7 \pm 0.33 \mu \mathrm{mol} / \mathrm{g} \\
\text { dry-weight glucoiberin) }\end{array}$ & $\begin{array}{l}400 \mathrm{~g} \text { garden } \\
\text { peas every } \\
\text { week }\end{array}$ & $\begin{array}{l}\text { TC (primary outcome), } \\
\text { SBP, DBP, HDL-C, LDL-C, } \\
\text { TG, ox-LDL, hsCRP, PWV, } \\
\text { Alx }\end{array}$ & $\leftrightarrow$ \\
\hline $\begin{array}{l}\text { Noah et al. (39), } \\
\text { USA, } \\
\text { NCT01269723 }\end{array}$ & $\begin{array}{l}\text { Randomized, } \\
\text { parallel, placebo- } \\
\text { controlled, } \\
\text { double-blind }\end{array}$ & $\begin{array}{l}\text { Healthy subjects } \\
\text { Smoker ASH group: } n=10(3 F, 7 M) \text { age } 28.1 \\
\pm 1.3 \mathrm{y}, \mathrm{BMl} 27.6 \pm 2 \mathrm{~kg} / \mathrm{m}^{2} \\
\text { Smoker BSH group: } n=6(2 \mathrm{~F}, 4 \mathrm{M}) \text { age } 27.3 \pm \\
1.7 \mathrm{y}, \mathrm{BMl} 27.2 \pm 1.4 \mathrm{~kg} / \mathrm{m}^{2} \\
\text { Non-smoker ASH group: } n=20(14 \mathrm{~F}, 6 \mathrm{M}) \text { age } \\
26.9 \pm 1.3 \mathrm{y}, \mathrm{BMl} 24.9 \pm 0.8 \mathrm{~kg} / \mathrm{m}^{2} \\
\text { Non-smoker BSH group: } n=15(7 \mathrm{~F}, 8 \mathrm{M}) \text { age } \\
26 \pm 1.3 \mathrm{y}, \mathrm{BMl} 25.5 \pm 0.9 \mathrm{~kg} / \mathrm{m}^{2}\end{array}$ & 4 days & $\begin{array}{l}200 \mathrm{~g} \mathrm{BSH} \\
\text { Composition: NA }\end{array}$ & $200 \mathrm{~g} \mathrm{ASH}$ & $\begin{array}{l}\text { IL-6 (primary outcome), } \\
\text { influenza B RNA sequence } \\
\text { quantity in NLF cells } \\
\text { NQO1 mRNA in NLF cells } \\
\text { IL-8, IP-10, INF- } \gamma, \mathrm{HO}-1 \\
\text { mRNA in NLF cells } \\
\text { Influenza B RNA sequence } \\
\text { quantity, HO-1 and NQO1 } \\
\text { mRNA in nasal biopsy }\end{array}$ & $\begin{array}{l}\downarrow \text { in smokers } \\
\uparrow \text { in smokers }\end{array}$ \\
\hline $\begin{array}{l}\text { Doss et al. (40), } \\
\text { USA, } \\
\text { NCT01715480 }\end{array}$ & $\begin{array}{l}\text { Non controlled, } \\
\text { baseline and } \\
\text { post-intervention }\end{array}$ & $\begin{array}{l}n=14 \text { patients with sickle cell disease } \\
50 \mathrm{~g} \text { BSH group: } n=5(2 \mathrm{~F}, 3 \mathrm{M}) \text { age } 31.8 \pm 5.5 \\
\mathrm{y} \\
100 \mathrm{~g} \text { BSH group: } n=5(2 \mathrm{~F}, 3 \mathrm{M}) \text { age } 37.4 \pm \\
9.3 \mathrm{y} \\
150 \mathrm{~g} \text { BSH group: } n=4(3 \mathrm{~F}, 1 \mathrm{M}) \text { age } 35.5 \pm \\
11.2 \mathrm{y}\end{array}$ & 21 days & $\begin{array}{l}\text { 50, } 100 \text {, or } 150 \mathrm{~g} \text { BSH daily } \\
\text { Composition: NA }\end{array}$ & NA & $\begin{array}{l}\text { Vital signs (primary } \\
\text { outcome), adverse signs } \\
\text { (primary outcome), HbF } \\
\text { (primary outcome) } \\
\text { Nrf2 genes expression in } \\
\text { sickle cells } \\
\text { Measurement of blood } \\
\text { chemistries, cell counts, } \\
\mathrm{LDH} \text { (primary outcome) }\end{array}$ & $\begin{array}{l}\leftrightarrow \\
\uparrow \mathrm{HO}-1 \text { with } 150 \mathrm{~g} \\
\text { and } \mathrm{HBG} 1 \text { with } \\
100 \mathrm{~g} \\
\downarrow \text { white blood cell } \\
\text { with } 150 \mathrm{~g}\end{array}$ \\
\hline $\begin{array}{l}\text { Duran et al. (41), } \\
\text { USA, } \\
\text { NCT01625130 }\end{array}$ & $\begin{array}{l}\text { Randomized, } \\
\text { crossover, } \\
\text { placebo- } \\
\text { controlled, } \\
\text { triple-blind }\end{array}$ & $\begin{array}{l}n=16 \text { healthy non-smoker subjects, age } \\
18-50 \text { y }\end{array}$ & 3 days & $\begin{array}{l}200 \mathrm{~g} \text { BSH daily } \\
\text { Composition: NA }\end{array}$ & $\begin{array}{l}200 \mathrm{~g} \mathrm{ASH} \\
\text { daily }\end{array}$ & $\begin{array}{l}\text { \% neutrophils in induced } \\
\text { sputum (primary outcome), } \\
\text { gene expression HO-1, } \\
\text { NQO-1, GSTM-1 } \\
\text { Plasma levels of SFN, } \\
\text { SFN-NAC, SFN-GSH }\end{array}$ & $\stackrel{\leftrightarrow}{\uparrow}$ \\
\hline
\end{tabular}

controlled,

Smoker BSH group: $n=6(2 F, 4 \mathrm{M})$ age $27.3 \pm$

$1.7 \mathrm{y}, \mathrm{BMI} 27.2 \pm 1.4 \mathrm{~kg} / \mathrm{m}^{2}$

y. BMl $25.5 \pm 0.9 \mathrm{~kg} / \mathrm{m}^{2}$

BSH group: $n=5(2 F, 3 \mathrm{M})$ age $31.8 \pm 5.5$

$9.3 y$

$150 \mathrm{~g}$ BSH group: $n=4$ (3F, 1M) age $35.5 \pm$

$n=16$ healthy non-smoker subjects, age

controlled 
TABLE 3 | Continued

\begin{tabular}{|c|c|c|c|c|c|c|c|}
\hline $\begin{array}{l}\text { Reference, } \\
\text { country, } \\
\text { registry ID }\end{array}$ & Study design & Study population & $\begin{array}{l}\text { Duration of } \\
\text { intervention }\end{array}$ & $\begin{array}{l}\text { Food or supplement } \\
\text { intervention }\end{array}$ & $\begin{array}{l}\text { Control or } \\
\text { placebo } \\
\text { intervention }\end{array}$ & $\begin{array}{l}\text { Primary outcome and } \\
\text { other variable outcomes }\end{array}$ & Main findings \\
\hline $\begin{array}{l}\text { Muller et al. (42), } \\
\text { USA, } \\
\text { NCT01269723 }\end{array}$ & $\begin{array}{l}\text { Randomized, } \\
\text { parallel, placebo- } \\
\text { controlled-double- } \\
\text { blind }\end{array}$ & $\begin{array}{l}n=29 \text { non-smokers healthy subjects } \\
\text { ASH group: } n=16(12 F, 4 \mathrm{M}) \text { age } 27.6 \pm 1.5 \mathrm{y} \\
\text { BMl } 25.1 \pm 1.0 \mathrm{~kg} / \mathrm{m}^{2} \\
\text { BSH group: } n=13(7 \mathrm{~F}, 6 \mathrm{M}) \text { age } 25.5 \pm 1.5 \mathrm{y} \\
\text { BMl } 25.5 \pm 1.1 \mathrm{~kg} / \mathrm{m}^{2}\end{array}$ & 4 days & $200 \mathrm{~g} \mathrm{BSH}(100 \mu \mathrm{mol}$ SFN $)$ & $200 \mathrm{~g} \mathrm{ASH}$ & $\begin{array}{l}\text { NKT cells in peripheral } \\
\text { blood } \\
\text { T cell, NK cells, } \\
\text { monocytes, macrophages, } \\
\text { neutrophils in the } \\
\text { peripheral blood, markers } \\
\text { of systemic NK cells } \\
\text { Granzyme B production in } \\
\text { NK cells }\end{array}$ & $\begin{array}{l}\downarrow \\
\leftrightarrow \\
\uparrow\end{array}$ \\
\hline $\begin{array}{l}\text { Sudini et al. (43), } \\
\text { USA, } \\
\text { NCT01183923 }\end{array}$ & $\begin{array}{l}\text { Randomized, } \\
\text { crossover, } \\
\text { placebo- } \\
\text { controlled, } \\
\text { triple-blind }\end{array}$ & $\begin{array}{l}n=40 \text { asthmatic adults, non-smoker } \\
\text { Broccoli sprouts group: } n=20(11 \mathrm{~F}, 9 \mathrm{M}) \text { age } \\
3.1 \pm 9.62 \mathrm{y}, \mathrm{BMl} 30.9(25.1-37.0) \mathrm{kg} / \mathrm{m}^{2} \\
\text { Placebo group: } n=20(13 \mathrm{~F}, 7 \mathrm{M}) \text { age } 34.2 \pm \\
9.17 \mathrm{y} \text {, BMl } 32.2 \mathrm{~kg} / \mathrm{m}^{2}\end{array}$ & 3 days & $100 \mathrm{~g}$ broccoli sprouts daily & $\begin{array}{l}100 \mathrm{~g} \text { alfalfa } \\
\text { sprouts daily }\end{array}$ & $\begin{array}{l}\text { Change in FENO (primary } \\
\text { outcome), FEV1, FVC, } \\
\text { asthmal control test score, } \\
\text { rhinitis quality of life score, } \\
\text { levels of HO-1, NQO1, } \\
\text { GCLC and GCLM, } \\
\text { antioxidant gene } \\
\text { expression in PBMCs, } \\
\text { urinary isoprostane, serum } \\
\text { TBARS levels, protein } \\
\text { carbonyl levels, IL-4, IL-13, } \\
\text { IL-6 levels }\end{array}$ & $\leftrightarrow$ \\
\hline $\begin{array}{l}\text { Langeveld et al. } \\
\text { (44), UK, } \\
\text { ISRCTN19147515 }\end{array}$ & $\begin{array}{l}\text { Randomized, } \\
\text { crossover, } \\
\text { placebo- } \\
\text { controlled, } \\
\text { single-blind }\end{array}$ & $\begin{array}{l}n=11 \text { healthy non-smoker subjects (5F) age } \\
33.7 \pm 6.9 \mathrm{y}, \mathrm{BMl} 22.9 \pm 0.9 \mathrm{~kg} / \mathrm{m}^{2} ;(6 \mathrm{M}) \text { age } \\
41.6 \pm 12.2 \mathrm{y}, \mathrm{BMI} 22.5 \pm 1.5 \mathrm{~kg} / \mathrm{m}^{2}\end{array}$ & $\begin{array}{l}3 \text { separate } \\
\text { days }\end{array}$ & $\begin{array}{l}10 \mathrm{~g} \text { capsulated mustard } \\
10 \mathrm{~g} \text { mustard } \\
\text { ( 1.6 mg } \\
\text { allyl-ITC/g mustard) }\end{array}$ & $\begin{array}{l}10 \mathrm{~g} \\
\text { capsulated } \\
\text { placebo } \\
\text { mixture } \\
\text { Composition: } \\
\text { tomato } \\
\text { ketchup, } \\
\text { olive } \\
\text { oil, water }\end{array}$ & $\begin{array}{l}\text { EE (primary outcome), } \\
\text { substrate oxidation, core } \\
\text { temperature, cold scores } \\
\text { hunger scores, El, plasma } \\
\text { glucose, plasma } \\
\text { non-esterified fatty acids, } \\
\text { plasma free thyroxin, } \\
\text { plasma cortisol }\end{array}$ & $\leftrightarrow$ \\
\hline $\begin{array}{l}\text { Nguyen et al. (45), } \\
\text { UK, } \\
\text { NCT01357070 }\end{array}$ & $\begin{array}{l}\text { Randomized, } \\
\text { crossover, } \\
\text { controlled, } \\
\text { double-blind }\end{array}$ & $\begin{array}{l}n=6 \text { healthy non-smokers subjects }(4 \mathrm{~F}, 2 \mathrm{M}) \\
\text { age } 26.5(24.5-29.3) \text { y, BMl } 20.2(19.1-21.3) \\
\mathrm{kg} / \mathrm{m}^{2}\end{array}$ & $24 \mathrm{~h}$ & $200 \mathrm{~g}$ of $\mathrm{BSH}$ & $200 \mathrm{~g}$ of $\mathrm{ASH}$ & $\begin{array}{l}\text { ROS activation in } \\
\text { leukocytes (primary } \\
\text { outcome), p38 MAP kinase } \\
\text { phosphorylation in } \\
\text { leukocytes (primary } \\
\text { outcome) } \\
\text { p65 Nf-kB activation in } \\
\text { leukocytes } \\
\text { (primary outcome) }\end{array}$ & $\begin{array}{l}\downarrow \\
\leftrightarrow\end{array}$ \\
\hline
\end{tabular}




\begin{tabular}{|c|c|c|c|c|c|c|c|}
\hline $\begin{array}{l}\text { Reference, } \\
\text { country, } \\
\text { registry ID }\end{array}$ & Study design & Study population & $\begin{array}{l}\text { Duration of } \\
\text { intervention }\end{array}$ & $\begin{array}{l}\text { Food or supplement } \\
\text { intervention }\end{array}$ & $\begin{array}{l}\text { Control or } \\
\text { placebo } \\
\text { intervention }\end{array}$ & $\begin{array}{l}\text { Primary outcome and } \\
\text { other variable outcomes }\end{array}$ & Main findings \\
\hline $\begin{array}{l}\text { Charron et al. (46), } \\
\text { USA, } \\
\text { NCT02346812 }\end{array}$ & $\begin{array}{l}\text { Randomized, } \\
\text { crossover, } \\
\text { controlled, single- } \\
\text { blind }\end{array}$ & $n=18$ healthy subjects & 18 days & $\begin{array}{l}100 \mathrm{~g} \text { broccoli and } 10 \mathrm{~g} \\
\text { daikon radish } 2 \text { times daily } \\
\text { for } 15 \text { days } \\
\text { On day } 16100 \mathrm{~g} \text { broccoli } \\
\text { and } 10 \mathrm{~g} \text { daikon radish } 1 \\
\text { time } \\
\text { On day } 17200 \mathrm{~g} \text { broccoli, } \\
20 \mathrm{~g} \text { daikon radish, } 100-\mathrm{g} \\
\text { roll and } 10 \mathrm{~g} \text { margarine } \\
(97.5 \mu \mathrm{mol} \text { GR and } 5.8 \\
\mu \mathrm{mol} \text { glucoerucin in } 200 \mathrm{~g} \\
\text { of broccoli) }\end{array}$ & $\begin{array}{l}\text { Diet without } \\
\text { broccoli or } \\
\text { other } \\
\text { Brassica } \\
\text { vegetables }\end{array}$ & $\begin{array}{l}\text { Plasma total ITCs } \\
\text { metabolites AUC (primary } \\
\text { outcome), Cmax } \\
\text { Plasma total ITCs } \\
\text { metabolites } \mathrm{k} \\
\text { Urine total ITCs } \\
\text { metabolites (primary } \\
\text { outcome), plasma total } \\
\text { ITCs metabolites Tmax, } \\
\text { lactulose:mannitol ratio }\end{array}$ & $\begin{array}{l}\uparrow \text { subjects with BMl } \\
<26 \mathrm{~kg} / \mathrm{m}^{2} \\
\downarrow \\
\leftrightarrow\end{array}$ \\
\hline $\begin{array}{l}\text { Lòpez-Chillòn et. } \\
\text { al. (47), Spain, } \\
\text { NCT03390855 }\end{array}$ & $\begin{array}{l}\text { Non controlled, } \\
\text { baseline and } \\
\text { post-intervention }\end{array}$ & $\begin{array}{l}n=40 \text { overweight subjects }(21 \mathrm{M}, 19 \mathrm{~F}) \text { age } 46 \\
\pm 6 \mathrm{y}, \mathrm{BMl} 28.9 \pm 4.0 \mathrm{~kg} / \mathrm{m}^{2}\end{array}$ & 10 weeks & $\begin{array}{l}30 \mathrm{~g} \text { fresh broccoli sprouts } \\
\text { daily ( } 51 \mathrm{mg} \text { GR, } 20 \mathrm{mg} \\
\text { neoglucobrassicin and } \\
121.11 \mathrm{mg} \text { total GSL per } \\
\text { dose) }\end{array}$ & NA & $\begin{array}{l}\text { Plasma levels of IL-6 and } \\
\text { CRP (primary outcome), } \\
\text { FM } \\
\text { Body weight, BMI } \\
\text { Urine GSL and ITCs level }\end{array}$ & $\begin{array}{l}\downarrow \\
\leftrightarrow \\
\uparrow\end{array}$ \\
\hline $\begin{array}{l}\text { Sivapalan et al. } \\
\text { (17), UK, } \\
\text { NCT02300324 }\end{array}$ & $\begin{array}{l}\text { Randomized, } \\
\text { crossover, } \\
\text { placebo- } \\
\text { controlled, } \\
\text { double-blind }\end{array}$ & $\begin{array}{l}n=10 \text { healthy subjects }(7 F, 3 M) \text { age } 42.9 \pm \\
17.4 \mathrm{y}, \mathrm{BMI} 25.2 \pm 3.2 \mathrm{~kg} / \mathrm{m}^{2}\end{array}$ & $\begin{array}{l}3 \text { separate } \\
\text { days }\end{array}$ & $\begin{array}{l}\text { Group 2: } 300 \mathrm{~g} \mathrm{Myb28}{ }^{\mathrm{B} / \mathrm{V}} \\
\text { broccoli (Beneforte } \\
\text { broccoli) and stilton soup } \\
\text { ( } 280 \pm 8.8 \mu \mathrm{mol} \text { GR per } \\
\text { portion) } \\
\text { Group 3: } 300 \mathrm{~g} \mathrm{Myb} 28^{\mathrm{V} / \mathrm{V}} \\
\text { broccoli and stilton soup } \\
\text { (452 } \pm 10.6 \mu \mathrm{mol} \text { GR } \\
\text { per portion) }\end{array}$ & $\begin{array}{l}\text { Group 1: } \\
300 \mathrm{~g} \\
\text { Myb28/B } \\
\text { broccoli } \\
\text { (standard } \\
\text { broccoli) and } \\
\text { stilton soup } \\
(84 \pm 2.8 \\
\mu \text { mol GR per } \\
\text { portion) }\end{array}$ & $\begin{array}{l}\text { Total excretion of SFN and } \\
\text { metabolites in } 24 \mathrm{~h} \text { urine } \\
\text { (primary outcome), plasma } \\
\text { level of SFN and its } \\
\text { metabolites AUC, Cmax, } \\
\text { Tmax, total excretion of GR } \\
\text { and glucoerucin in urine, } \\
\text { AUC, Cmax }\end{array}$ & $\uparrow$ \\
\hline $\begin{array}{l}\text { Chen et al. (48), } \\
\text { China, } \\
\text { NCT02656420 }\end{array}$ & $\begin{array}{l}\text { Randomized, } \\
\text { parallel, placebo- } \\
\text { controlled, } \\
\text { single-blind }\end{array}$ & $\begin{array}{l}n=170 \text { healthy subjects } \\
\text { Placebo group: } n=55(38 F, 17 \mathrm{M}) \text { age } 56 \\
\text { (53-61) y, BMI } 25.1(23.1-26.7) \mathrm{kg} / \mathrm{m}^{2} \\
\text { 1/5 dose group: } n=55(43 F, 12 \mathrm{M}) \text { age } 60 \\
(53-63) \text { y, BMI } 24.7(22.6-26.8) \mathrm{kg} / \mathrm{m}^{2} \\
\text { 1/2 dose group: } n=35(28 \mathrm{~F}, 7 \mathrm{M}) \text { age } 58 \\
\text { (50-64) y, BMI } 23.9(22.1-26.6) \mathrm{kg} / \mathrm{m}^{2} \\
\text { Full dose group: } n=25(18 \mathrm{~F}, 7 \mathrm{M}) \text { age } 59 \\
\text { (56-62) y, BMI } 23.5(21.6-25.8) \mathrm{kg} / \mathrm{m}^{2}\end{array}$ & 10 days & $\begin{array}{l}\text { Full dose: } 100 \mathrm{ml} \text { broccoli } \\
\text { sprouts beverage with } \\
\text { pineapple juice, lime juice } \\
\text { and water, nightly } \\
(600 \mu \mathrm{mol} \text { GR and } 40 \\
\mu \mathrm{mol} \text { SFN) } 1 / 2 \text { dose: } \\
100 \mathrm{ml} \text { broccoli sprouts } \\
\text { beverage with pineapple } \\
\text { juice, lime juice and water, } \\
\text { nightly ( } 300 \mu \mathrm{mol} \text { GR and } \\
20 \mu \mathrm{mol} \text { SFN) } \\
1 / 5 \text { dose: broccoli sprouts } \\
\text { beverage with pineapple } \\
\text { juice, lime juice and water, } \\
\text { nightly (120 } \mu \text { mol GR and } \\
8 \mu \mathrm{mol} \text { SFN) }\end{array}$ & $\begin{array}{l}100 \mathrm{ml} \\
\text { beverage } \\
\text { containing } \\
\text { pineapple } \\
\text { juice, lime } \\
\text { juice and } \\
\text { water. } \\
\text { Nightly }\end{array}$ & $\begin{array}{l}\text { Urinary excretion of } \\
\text { S-phenylmercapturic acid }\end{array}$ & $\uparrow$ full dose \\
\hline
\end{tabular}


TABLE 3 | Continued

\begin{tabular}{|c|c|c|c|c|c|c|c|}
\hline $\begin{array}{l}\text { Reference, } \\
\text { country, } \\
\text { registry ID }\end{array}$ & Study design & Study population & $\begin{array}{l}\text { Duration of } \\
\text { intervention }\end{array}$ & $\begin{array}{l}\text { Food or supplement } \\
\text { intervention }\end{array}$ & $\begin{array}{l}\text { Control or } \\
\text { placebo } \\
\text { intervention }\end{array}$ & $\begin{array}{l}\text { Primary outcome and } \\
\text { other variable outcomes }\end{array}$ & Main findings \\
\hline $\begin{array}{l}\text { Coode-Bate et al. } \\
\text { (49), UK, } \\
\text { NCT02821728 }\end{array}$ & $\begin{array}{l}\text { Randomized, } \\
\text { parallel, controlled }\end{array}$ & $\begin{array}{l}n=18 \text { healthy males scheduled for prostate } \\
\text { biopsy } \\
\text { Control group: } n=9 \text {, age } 64.7 \pm 5.39 \mathrm{y}, \mathrm{BMl} \\
26.8 \pm 3.29 \mathrm{~kg} / \mathrm{m}^{2} \\
\text { Supplementation group: } n=9 \text {, age } 68.8 \pm \\
6.46 \mathrm{y}, \mathrm{BMl} 28.1 \pm 2.58 \mathrm{~kg} / \mathrm{m}^{2}\end{array}$ & 4 weeks & $\begin{array}{l}300 \mathrm{~g} \text { GR-rich broccoli } \\
\text { soup per week }(280 \pm 8.8 \\
\mu \mathrm{mol} \text { GR per portion and } \\
1,513 \pm 36.8 \mu \mathrm{mol} \text { of } \\
\text { SMCSO) }\end{array}$ & Habitual diet & $\begin{array}{l}\text { Sulfate levels in prostate } \\
\text { tissues (primary outcome), } \\
\text { SMCSO in periprostatic } \\
\text { adipose tissue } \\
\text { SMCSO levels in prostate } \\
\text { tissues, SMCSO in urine }\end{array}$ & $\stackrel{\leftrightarrow}{\uparrow}$ \\
\hline $\begin{array}{l}\text { Traka et al. (11), } \\
\text { UK, } \\
\text { ISRCTN40496794 }\end{array}$ & $\begin{array}{l}\text { Randomized, } \\
\text { 3-arm parallel, } \\
\text { placebo- } \\
\text { controlled, } \\
\text { double-blind }\end{array}$ & $\begin{array}{l}n=49 \text { males with diagnosis of low-risk or } \\
\text { intermediate-risk prostate cancer } \\
\text { Soup X group (control): } n=16 \text {, age } 68 \pm 5 \mathrm{y} \text {, } \\
\text { BMl } 26.7 \pm 3.1 \mathrm{~kg} / \mathrm{m}^{2} \\
\text { Soup Y group: } \mathrm{n}=17 \text {, age } 66 \pm 6 \mathrm{y} \text {, BMl } 27.6 \\
\pm 3.4 \mathrm{~kg} / \mathrm{m}^{2} \\
\text { Soup Z group: } \mathrm{n}=16 \text {, age } 66 \pm 6 \mathrm{y} \text {, BMl } 27.7 \\
\pm 2.2 \mathrm{~kg} / \mathrm{m}^{2}\end{array}$ & $\begin{array}{l}12 \text { months + } \\
\text { optional } 12 \\
\text { months }\end{array}$ & $\begin{array}{l}\text { Broccoli soup Y (genotype } \\
\text { Myb28 BN): } \\
300 \mathrm{ml} \text { weekly } \\
(214 \pm 7.3 \mu \mathrm{mol} \text { GR) } \\
\text { Broccoli soup Z (genotype } \\
\text { Myb28 VN): } \\
300 \mathrm{ml} \text { weekly } \\
(492 \pm 3.2 \mu \mathrm{mol} \text { GR) }\end{array}$ & $\begin{array}{l}\text { Broccoli } \\
\text { soup } X \\
\text { (genotype } \\
\text { Myb28 B/B): } \\
300 \mathrm{ml} \\
\text { weekly } \\
(72 \pm 2.8 \\
\mu \mathrm{mol} \text { GR) }\end{array}$ & $\begin{array}{l}\text { Prostate cancer } \\
\text { biomarkers measured in } \\
\text { prostate tissue (primary } \\
\text { outcome) } \\
\text { Metabolomics analysis }\end{array}$ & $\begin{array}{l}\downarrow \\
\leftrightarrow\end{array}$ \\
\hline $\begin{array}{l}\text { Charron et al. (46), } \\
\text { USA, } \\
\text { NCT03013465 }\end{array}$ & $\begin{array}{l}\text { Randomized, } \\
\text { crossover, } \\
\text { controlled, } \\
\text { single-blind }\end{array}$ & $\begin{array}{l}n=17 \text { healthy subjects }(9 F, 8 M) \text { age } 54.3 \pm \\
9.2 y, \text { BMl } 26.9 \pm 4.3 \mathrm{~kg} / \mathrm{m}^{2}\end{array}$ & 16 days & $\begin{array}{l}200 \mathrm{~g} \text { cooked broccoli } \\
\text { daily, } \\
100 \mathrm{~g} \text { of broccoli on day } \\
16, \\
200 \mathrm{~g} \text { of broccoli, } 100 \mathrm{~g} \text { roll } \\
\text { and } 10 \mathrm{~g} \text { of margarine on } \\
\text { day } 17 \\
(147.6 \mu \text { mol GR and } 3.6 \\
\mu \text { mol glucoerucin in } 200 \mathrm{~g} \\
\text { of broccoli) }\end{array}$ & $\begin{array}{l}\text { No broccoli } \\
\text { consumption }\end{array}$ & $\begin{array}{l}\text { Percentage of total plasma } \\
\text { AUC, plasma total } \\
\text { metabolites Cmax, T max, } \\
\text { k, total urinary } \\
\text { accumulation (primary } \\
\text { outcomes) }\end{array}$ & $\leftrightarrow$ \\
\hline
\end{tabular}

AIx, augmentation index; ASH, alfalfa sprouts homogenate; AUC, area under curve; BMI, body mass index; BP, blood pressure; BSH, broccoli sprouts homogenate; Cmax, maximum concentration; CRP, C-reactive protein; CVD, cardiovascular disease; EE, energy expenditure; El, energy intake; FENO, fractional exhaled nitric oxide; FEV1, forced expiratory volume; FM, body fat mass; FMD, flow mediated vasodilatation; FVC, forced vital capacity; DBP. Diastolic blood pressure; GCLC, glutamate cysteine ligase catalytic subunit; GCLM, glutamate cysteine ligase modifier subunit; GR, glucoraphanin; GSL, glucosinolates; GSTM1, glutathione S-transferase Mu 1; HbF, fetal hemoglobin; HBG1, hemoglobin subunit gamma 1; HDL-C, high-density lipoprotein cholesterol; HO-1, heme oxygenase-1; hsCRP, high-sensitive C-reactive protein; IL-13, Interleukin 13; IL-4, Interleukin 4; IL-6, Interleukin-6; IL-8, Interleukin-8; INF-y, Interferon gamma; IP-10, Interferon gamma-induced protein 10; ITCs, isothiocyanates; $k$, elimination rate constant; LDH, lactate dehydrogenase; LDL-C, Iow-density lipoprotein cholesterol; NA, not available; Nf-kB, nuclear factor kappalight-chain-enhancer of activated B cells; NK, natural killer; NKT, natural killer T; NLF, nasal lavage fluid; NQ01, NADPH quinone oxidoreductase-1; Nrf2, nuclear factor erythroid-2 related factor 2; Ox-LDL, oxidized low-density lipoprotein cholesterol; PBMC, peripheral blood mononuclear cell; PW, pulse-wave velocity; ROS, reactive oxygen species; SBP, systolic blood pressure; SFN, sulforaphane; SFN-GSH, sulforaphane-glutathione; SFN-NAC, sulforaphane-N-acetylL-cysteine; SMCSO, S-methyl cysteine sulfoxide; TBARS, thiobarbituric acid reactive substances; TC, total cholesterol; TG, tryglicerides; Tmax, time of maximum concentration; $\downarrow$, significant decrease; $\uparrow$, significant increase; $\leftrightarrow$, no significant effect. 
TABLE 4 | Characteristics and findings of publications associated with the registered trials on extracts or pure compounds.

\begin{tabular}{|c|c|c|c|c|c|c|c|}
\hline $\begin{array}{l}\text { Reference, } \\
\text { country, registry } \\
\text { ID }\end{array}$ & Study design & Study population & $\begin{array}{l}\text { Duration of } \\
\text { intervention }\end{array}$ & Food or supplement intervention & $\begin{array}{l}\text { Control or } \\
\text { placebo } \\
\text { intervention }\end{array}$ & $\begin{array}{l}\text { Primary outcome and } \\
\text { other variable outcomes }\end{array}$ & Main findings \\
\hline $\begin{array}{l}\text { Poulton et al. (50), } \\
\text { USA, } \\
\text { NCT00621309 }\end{array}$ & $\begin{array}{l}\text { Randomized, } \\
\text { crossover, } \\
\text { controlled }\end{array}$ & $\begin{array}{l}n=23 \text { healthy non-smoker } \\
\text { subjects (11F, 12M) age } 23.7 \mathrm{y} \\
(20-37 \mathrm{y}), \mathrm{BMl} 23.4 \pm 2.7 \mathrm{~kg} / \mathrm{m}^{2}\end{array}$ & 7 days & $\begin{array}{l}\text { Group 1: } 450 \mu \mathrm{mol} \text { SFN (BSE) + cheese } \\
\text { soup daily } \\
\text { Group 2: } 450 \mu \mathrm{mol} \text { SFN (BSE) + cheese } \\
\text { soup and } 300 \mathrm{mg} \text { rifampicin daily }\end{array}$ & $\begin{array}{l}\text { Group 3: } \\
\text { cheese soup } \\
\text { and } 300 \mathrm{mg} \\
\text { rifampicin } \\
\text { daily }\end{array}$ & $\begin{array}{l}\text { Pharmacokinetic Measure } \\
\text { of Cytochrome P450 3A4 } \\
\text { Activity (primary outcome) }\end{array}$ & $\leftrightarrow$ \\
\hline $\begin{array}{l}\text { Haber et al. (51), } \\
\text { USA, } \\
\text { NCT00882115 }\end{array}$ & $\begin{array}{l}\text { Non controlled, } \\
\text { baseline and } \\
\text { post-intervention }\end{array}$ & $\begin{array}{l}n=28 \text { healthy subjects }(14 \mathrm{~F}, \\
14 \mathrm{M})\end{array}$ & 4 days & $1.25 \mathrm{~g} \mathrm{BSE}(100 \mu \mathrm{mol} \mathrm{SFN})$ & NA & $\begin{array}{l}\text { Total number of nasal } \\
\text { leukocytes (primary } \\
\text { outcome) }\end{array}$ & $\downarrow$ \\
\hline $\begin{array}{l}\text { Singh et al. (52), } \\
\text { USA, } \\
\text { NCT01474993 }\end{array}$ & $\begin{array}{l}\text { Randomized, } \\
\text { parallel, placebo- } \\
\text { controlled, } \\
\text { quadruple-blind }\end{array}$ & $\begin{array}{l}n=40 \text { males patients with ASD, } \\
\text { age } 13-27 \text { y } \\
\text { SFN treated group: } n=26 \\
\text { Placebo group: } n=14\end{array}$ & 18 weeks & $\begin{array}{l}\text { SFN-rich BSE: } \\
50 \mu \mathrm{mol} \text { SFN for weight }<100 \mathrm{lb} \\
100 \mu \mathrm{mol} \text { SFN for weight }=101-199 \mathrm{lb} \\
150 \mu \mathrm{mol} \text { SFN for weight }>200 \mathrm{lb}\end{array}$ & $\begin{array}{l}\text { Microcrystalline } \\
\text { cellulose }\end{array}$ & $\begin{array}{l}\text { SRS (primary outcome), } \\
\text { ABCS } \\
\text { CGI-I }\end{array}$ & $\begin{array}{l}\downarrow \\
\uparrow\end{array}$ \\
\hline $\begin{array}{l}\text { Atwell et al. (53), } \\
\text { USA, } \\
\text { NCT00843167 }\end{array}$ & $\begin{array}{l}\text { Randomized, } \\
\text { parallel, placebo- } \\
\text { controlled, } \\
\text { triple-blind }\end{array}$ & $\begin{array}{l}n=54 \text { females with diagnostic } \\
\text { mammogram, age } 54 \pm 12 \mathrm{y} \\
\text { BMl } 27.3 \pm 5.6 \mathrm{~kg} / \mathrm{m}^{2}\end{array}$ & 2-8 weeks & $\begin{array}{l}\sim 250 \mathrm{mg} \text { broccoli seed extract, } 2 \text { pills } \\
3 \times / \text { day (224 mg GR total daily dose) }\end{array}$ & $\begin{array}{l}\text { Microcrystalline } \\
\text { cellulose } \\
3 \times / \text { day }\end{array}$ & $\begin{array}{l}\text { Urinary levels of ITCs } \\
\text { (primary outcome) } \\
\text { HDA Activity (primary } \\
\text { outcome) } \\
\text { Ki-67 (primary outcome), } \\
\text { HDAC3 } \\
\text { H3K9ac } \\
\text { p21, HDAC6, H3K18ac }\end{array}$ & $\begin{array}{l}\uparrow \\
\downarrow \\
\downarrow \text { in benign tissues } \\
\text { in the SFN group } \\
\downarrow \text { in ductal } \\
\text { carcinoma tissue in } \\
\text { the placebo group } \\
\leftrightarrow\end{array}$ \\
\hline $\begin{array}{l}\text { Rajendran et al. } \\
\text { (54), USA, } \\
\text { NCT01543074 }\end{array}$ & $\begin{array}{l}\text { Randomized, } \\
\text { parallel, placebo- } \\
\text { controlled, } \\
\text { double-blind }\end{array}$ & $\begin{array}{l}n=10 \text { healthy subjects } \\
\text { BSE group: } n=5 \\
\text { Placebo group: } n=5\end{array}$ & 7 days & $200 \mu \mathrm{mol}$ SFN equivalent of BSE & Placebo & $\begin{array}{l}\text { Blood levels of SFN and its } \\
\text { metabolites }\end{array}$ & $\uparrow$ \\
\hline $\begin{array}{l}\text { Shiina et al. (55), } \\
\text { Japan, } \\
\text { NCT01716858 }\end{array}$ & $\begin{array}{l}\text { Non controlled, } \\
\text { baseline and } \\
\text { post-intervention }\end{array}$ & $\begin{array}{l}n=10 \text { patients with } \\
\text { schizophrenia (6F, 4M) age } 42.7 \\
\pm 11 \mathrm{y}\end{array}$ & 8 weeks & 30 mg SFN-GSL daily & NA & $\begin{array}{l}\text { PNSS (primary outcome), } \\
\text { Levels of brain-derived } \\
\text { neurotrophic factors } \\
\text { CogState }\end{array}$ & $\begin{array}{l}\leftrightarrow \\
\uparrow \text { only in the } \\
\text { Accuracy } \\
\text { component of the } \\
\text { One Card } \\
\text { Learning Task }\end{array}$ \\
\hline $\begin{array}{l}\text { Yuan et al. (56), } \\
\text { USA, } \\
\text { NCT00691132 }\end{array}$ & $\begin{array}{l}\text { Randomized, } \\
\text { crossover, } \\
\text { placebo- } \\
\text { controlled, } \\
\text { double-blind }\end{array}$ & $\begin{array}{l}n=82 \text { healthy current smokers } \\
(38 \mathrm{~F}, 44 \mathrm{M}) \text { age } 41 \pm 10.1 \mathrm{y}, \mathrm{BMl} \\
28 \pm 5.6 \mathrm{~kg} / \mathrm{m}^{2}\end{array}$ & 5 weeks & $\begin{array}{l}10 \mathrm{mg} \text { of PEITC in } 1 \mathrm{ml} \text { olive oil, } 4 \\
\text { times/day, once every } 4 \mathrm{~h} \text { for } 5 \text { days }\end{array}$ & $\begin{array}{l}\text { Olive oil, } 4 \\
\text { times/day, } \\
\text { once every } \\
4 \text { h for } 5 \\
\text { days }\end{array}$ & $\begin{array}{l}\text { Urinary levels of total ITCs } \\
\text { and PEITC-NAC (primary } \\
\text { outcome) } \\
\text { The ratio of urinary } \\
\text { [pyridine-D4]hydroxy acid: } \\
\text { total [pyridine-D4]NNAL } \\
\text { (primary outcome), urinary } \\
\text { levels of PEITC-NAC and } \\
\text { total ITCs by GSTM1 or } \\
\text { both genotypes GSTM1 } \\
\text { and GSTT1 } \\
\text { Urinary levels of } \\
\text { PEITC-NAC and total ITCs } \\
\text { by GSTT1 genotypes }\end{array}$ & $\leftrightarrow$ \\
\hline
\end{tabular}


TABLE 4 | Continued

\begin{tabular}{|c|c|c|c|c|c|c|c|}
\hline $\begin{array}{l}\text { Reference, } \\
\text { country, registry } \\
\text { ID }\end{array}$ & Study design & Study population & $\begin{array}{l}\text { Duration of } \\
\text { intervention }\end{array}$ & Food or supplement intervention & $\begin{array}{l}\text { Control or } \\
\text { placebo } \\
\text { intervention }\end{array}$ & $\begin{array}{l}\text { Primary outcome and } \\
\text { other variable outcomes }\end{array}$ & Main findings \\
\hline $\begin{array}{l}\text { Wise et al. (57), } \\
\text { USA, } \\
\text { NCT01335971 }\end{array}$ & $\begin{array}{l}\text { Randomized, } \\
\text { 3-arm parallel, } \\
\text { placebo- } \\
\text { controlled, } \\
\text { quadruple-blind }\end{array}$ & $\begin{array}{l}n=89 \text { smoker with physician } \\
\text { diagnosed COPD subjects } \\
\text { Placebo group: } n=31 \text { (15F, } \\
\text { 16M) age } 59(52-67) \\
\text { Group 1: } n=29(12 F, 17 \mathrm{M}) \text { age } \\
59(54-65) \text { y } \\
\text { Group 2: } n=29(8 F, 21 \mathrm{M}) \text { age } \\
56(52-62) \text { y }\end{array}$ & 1 month & $\begin{array}{l}\text { Group 1: } 25 \mu \mathrm{mol} \text { SFN daily } \\
\text { Group 2: } 150 \mu \mathrm{mol} \text { SFN daily }\end{array}$ & $\begin{array}{l}\text { Microcrystalline } \\
\text { cellulose }\end{array}$ & $\begin{array}{l}\text { Alveolar macrophage } \\
\text { expression of Nrf2, NQ01, } \\
\text { HO1, AKR1C1, AKR1C3 } \\
\text { (primary outcome), } \\
\text { bronchial epithelial cell } \\
\text { expression of Nrf2, NQ01, } \\
\text { HO1, AKR1C1, AKR1C3 } \\
\text { (primary outcome), } \\
\text { isoprostane, TBARS in } \\
\text { plasma and expired breath } \\
\text { condensate, cytokine } \\
\text { profiles in bronchoalveolar } \\
\text { lavage fluid }\end{array}$ & $\leftrightarrow$ \\
\hline $\begin{array}{l}\text { Axelsson et al. } \\
\text { (58), Sweden, } \\
\text { NCT02801448 }\end{array}$ & $\begin{array}{l}\text { Randomized, } \\
\text { parallel, placebo- } \\
\text { controlled, } \\
\text { quadruple-blind }\end{array}$ & $\begin{array}{l}n=97 \text { patients with type } 2 \\
\text { diabetes }(24 \mathrm{~F}, 73 \mathrm{M}) \text { age } 35-75 \mathrm{y} \\
\text { BMl } 30.4 \pm 4.0 \mathrm{~kg} / \mathrm{m}^{2}\end{array}$ & 12 weeks & $150 \mu \mathrm{mol}$ SFN in BSE daily & $\begin{array}{l}\text { Maltodextrin } \\
\text { sprayed with } \\
\text { copper } \\
\text { chlorophyllin }\end{array}$ & $\begin{array}{l}\text { HbA1c (primary outcome) } \\
\text { Fasting blood glucose } \\
\text { BMI, Fatty liver index, liver } \\
\text { parameters, TC, TG, Hb }\end{array}$ & $\begin{array}{l}\downarrow \\
\downarrow \text { in obese } \\
\text { dysregulated T2D } \\
\text { patients } \\
\leftrightarrow\end{array}$ \\
\hline $\begin{array}{l}\text { Bent et al. (59), } \\
\text { USA, } \\
\text { NCT02654743 }\end{array}$ & $\begin{array}{l}\text { Non controlled, } \\
\text { baseline and } \\
\text { post-intervention }\end{array}$ & $\begin{array}{l}n=15 \text { child with ASD }(3 F, 12 \mathrm{M}) \\
\text { age } 14.7 \mathrm{y}\end{array}$ & 12 weeks & $\begin{array}{l}1 \mu \mathrm{mol} \text { SFN/2.2 kg body weight daily with } \\
\text { tablets, each one containing } 125 \mathrm{mg} \mathrm{BSE} \text {, } \\
50 \mathrm{mg} \text { dried broccoli sprouts, } 15 \mathrm{mg} \\
\text { ascorbic acid and microcrystalline } \\
\text { cellulose }\end{array}$ & NA & $\begin{array}{l}\text { ABCS } \\
\text { SRS }\end{array}$ & $\begin{array}{l}\uparrow \\
\uparrow\end{array}$ \\
\hline $\begin{array}{l}\text { Liu et al. (60), } \\
\text { USA, } \\
\text { NCT02561481 }\end{array}$ & $\begin{array}{l}\text { Non controlled, } \\
\text { baseline and } \\
\text { post-intervention }\end{array}$ & $\begin{array}{l}n=10 \text { young males with ASD, } \\
\text { age } 9.9 \mathrm{y}\end{array}$ & 14 days & $\begin{array}{l}12.5-15 \mathrm{mg} \text { GR }(2.2 \mu \mathrm{mol} \text { SFN/kg body } \\
\text { weight) and active plant-derived } \\
\text { myrosinase daily }\end{array}$ & NA & $\begin{array}{l}\text { NQO1, AKR1C1, HO-1, } \\
\text { HSP70, HSP27 } \\
\text { IL-6, IL-1 } 1 \beta, \text { TNF- } \alpha \text {, Cox-2 }\end{array}$ & $\overleftrightarrow{\downarrow}$ \\
\hline $\begin{array}{l}\text { Zhang et al. (61), } \\
\text { USA, } \\
\text { NCT01265953 }\end{array}$ & $\begin{array}{l}\text { Randomized, } \\
\text { parallel, placebo- } \\
\text { controlled, } \\
\text { triple-blind }\end{array}$ & $\begin{array}{l}n=98 \text { males at risk for prostate } \\
\text { cancer } \\
\text { Placebo group: } n=48, \text { age } 64.9 \\
\pm 5 \mathrm{y}, \text { BMl } 31.1 \mathrm{~kg} / \mathrm{m}^{2} \\
\text { BSE group: } n=50, \text { age } 65.7 \mathrm{y} \\
\text { BMI } 28.9 \mathrm{~kg} / \mathrm{m}^{2}\end{array}$ & 4-8 weeks & 2 of BSE capsules daily ( $200 \mu \mathrm{mol}$ SFN) & $\begin{array}{l}\text { Gelatin } \\
\text { capsule with } \\
\text { microcrystalline } \\
\text { cellulose }\end{array}$ & $\begin{array}{l}\text { Total urine SFN metabolites } \\
\text { (primary outcome), Total } \\
\text { plasma SFN metabolites } \\
\text { (primary outcome) } \\
\text { PBMC HDAC activity levels } \\
\text { Tissue levels of H3K18ac, } \\
\text { HDAC3, HDAC6 (primary } \\
\text { outcome), Ki-67 (primary } \\
\text { outcome), p21 } \\
\text { ARLNC1 and AMACR } \\
\text { gene expression }\end{array}$ & $\begin{array}{l}\uparrow \\
\uparrow \text { in subjects with } \\
\text { prostate cancer } \\
\leftrightarrow \\
\downarrow \text { in prostate } \\
\text { cancer tissue }\end{array}$ \\
\hline
\end{tabular}

ABCS, Aberrant Behavior Checklist scale; AKR1C1, aldo-keto reductase Family 1 Member C1; AKR1C3, aldo-keto reductase Family 1 Member C3; AMACR, alpha-methylacyl-CoA racemase; ARLNC1, androgen receptor-regulated long noncoding RNA; ASD, Autism Spectrum Disorder; BMI, body mass index; BSE, broccoli sprouts extract; CGI-I, Clinical Global Impression Improvement Scale; COPD, chronic obstructive pulmonary disease; Cox2, cyclooxygenase-2; GR, glucoraphanin; GSTM1, glutathione S-transferase MU 1; GSTT1, glutathione S-transferase theta-1; H3K18ac, acetylated histone H3 lysine 18; H3K9ac, acetylated histone H3 lysine 9; Hb, hemoglobin; HDA1c, glycated hemoglobin; HDAC, histone deacetylase; HDAC3, histone deacetylase 3; HDAC6, histone deacetylase 6; HO-1, heme oxygenase-1; HSP27, heat shock protein 70; HSP7O, heat shock protein 70; IL-1 $\beta$, Interleukin-1 1 ; IL-6, Interleukin-6; ITCs, isothiocyanates; NA, not available; NQ01, NADPH quinone oxidoreductase-1; Nif2, nuclear factor erythroid-2 related factor 2; PBMC, peripheral blood mononuclear cell; PEITC, 2-phenethyl isothiocyanate; PEITC-NAC, N-acetyl-S-(N2-phenethylthiocarbamoyl)-L-cysteine; PNSS, Positive and Negative Syndrome Scale; SFN, sulforaphane; SRS, Social Responsiveness Scale; T2D, type 2 diabetes; TBARS, thiobarbituric acid reactive substances; TC, total cholesterol; TG, tryglicerides; TNF- $\alpha$, Tumor Necrosis Factor- $\alpha$; $\downarrow$, significant decrease; $\uparrow$, significant increase; $\leftrightarrow$, no significant effect. 
$\mu \mathrm{mol}$ of SFN in total) in a group of subjects scheduled for prostate biopsy.

Concerning the effects on human health with pure GSLs, Wise and coworkers (57) found no differences in Nrf2 target gene expression such as NQO1, HO1, aldo-keto reductase Family 1 Member C1 (AKR1C1), and aldo-keto reductase Family 1 Member C3 (AKR1C3) in alveolar macrophages and bronchial epithelial cells after intervention with $150 \mu \mathrm{mol}$ SFN daily by mouth for 4 weeks in smoker subjects with physician diagnosed chronic obstructive pulmonary disease (COPD).

Regarding the effect of GSLs on cancer biomarkers, Atwell et al. (53) evaluated the role of SFN on PBMCs histone deacetylase (HDAC) activity, and tissue biomarkers (H3K18ac, H3K9ac, HDAC3, HDAC6, Ki-67, p21) in women with abnormal mammograms and scheduled for breast biopsy. After 2-8 weeks of supplementation with $250 \mathrm{mg}$ of broccoli seed extract containing $30 \mathrm{mg}$ of GR, the authors found a significant decrease in PBMC HDAC activity in the SFN group compared with the placebo group, while no significant effect was observed on examined tissue biomarkers. Conversely, in a total of 98 men scheduled for prostate biopsy, Zhang et al. (61) did not find significant differences in HDAC activity following the intervention with broccoli sprout extract (BSE) $(200 \mu \mathrm{mol}$ SFN) compared to the placebo. However, within the subgroup of subjects with a confirmed prostate cancer diagnosis, SFN showed a significant increase in HDAC activity.

Other prevalent biomarkers investigated were those related to cognitive function. A placebo-controlled, double-blind, randomized trial (52) showed the beneficial role of 50-150 $\mu \mathrm{mol}$ of SFN supplemented in young men (age 13-27) with moderate to severe autism spectrum disorder. The intervention with broccoli sprouts extract, rich in SFN, for 18 weeks was able to significantly improve behavioral measures such as the Aberrant Behavior Checklist (ABC), Social Responsiveness Scale (SRS), and Clinical Global Impression Improvement Scale (CGII) compared to the placebo group. Also Bent and coworkers (59) reported an improvement of specific symptoms of autism spectrum disorder in children and young adults following SFN supplementation. In particular, the study participants received daily SFN tablets ( $\sim 2.5 \mu \mathrm{mol} \mathrm{GR})$ for 12 weeks, and at the end of the study, both the ABC and the SRS parameters showed an improvement.

Although several biomarkers were positively modulated by the intervention with GSL-rich foods and GSL-rich extracts/pure compounds, different studies reported an apparent null effect on lipid profile and vascular function. For instance, a randomized, 3-arm parallel, controlled study (38) found no effect on total cholesterol (TC), systolic blood pressure (SBP), diastolic blood pressure (DBP), high-density lipoprotein cholesterol (HDLC), low-density lipoprotein cholesterol (LDL-C), triglycerides (TG), oxidized LDL (ox-LDL), high-sensitivity C-reactive protein (hsCRP), pulse wave velocity (PWV), and augmentation index (Aix) following 12-week dietary intervention with $400 \mathrm{~g}$ of highGR broccoli $(21.6 \pm 1.60 \mu \mathrm{mol} / \mathrm{g}$ dry-weight GR and $4.5 \pm$ $0.34 \mu \mathrm{mol} / \mathrm{g}$ dry-weight glucoiberin) compared with standard broccoli $(6.9 \pm 0.44 \mu \mathrm{mol} / \mathrm{g}$ dry-weight $\mathrm{GR}$ and $0.7 \pm 0.33$ $\mu \mathrm{mol} / \mathrm{g}$ dry-weight glucoiberin) or peas. Also, Christiansen et al.
(37) did not observe an improvement in FMD as a marker of vascular function, as well as BP, HDL-C, and LDL-C in hypertensive individuals after 4-week period intervention with $10 \mathrm{~g}$ of dried broccoli sprouts daily $(25.9 \pm 8.5 \mu \mathrm{mol} / \mathrm{g}$ dryweight GR; $48.5 \pm 14.2 \mu \mathrm{mol} / \mathrm{g}$ dry-weight total GSLs) compared to the habitual diet. Similarly, Axelsson et al. (58) reported no significant effect of SFN (daily dose of $150 \mu \mathrm{mol}$ for 12 weeks) on TC and TG compared with the placebo group in patients with type 2 diabetes.

\section{DISCUSSION}

The study of the role of GSLs and GSL-rich foods on human health has received increasing interest, as documented by the boost of human intervention trials carried out on this topic. Our review was focused on analyzing the trend of the registered studies on GSLs by using ClinicalTrials.gov and ISRCTN registry as databases. In this study, we summarized the main characteristics of the studies in order to provide a general and broad overview in the research field of GSLs to sum up what has already been done including the main gaps to be filled and, in turn, how and where to direct new efforts on this field.

\section{Studies Performed on GSL-Rich Foods}

Regarding foods, numerous epidemiological studies have shown an inverse association between the consumption of GSL-rich foods (i.e., broccoli, kale, cabbage, and cauliflower) and the risk of different types of cancer, including colorectal, breast, and prostate cancer $(27,62,63)$. In this study, we documented that most of the registered clinical trials were focused on broccoli, in line with the trials registered on the extracts, while very few dietary interventions were registered on other brassica vegetables. These studies included Brussel sprout, kale, mustard, and watercress (64-69). One possible explanation could be related to their limited human consumption and generally restricted to certain populations. However, the effects of these brassica vegetables on human health have been investigated in the past both through observational and intervention studies (70-72). The main topics included the evaluation of oxidative stress and cardiometabolic markers. These research themes have been partially confirmed in the current revision even if the actual research trend on these vegetables includes the evaluation of the metabolism of polycyclic aromatic hydrocarbons, the study of cell phase angle (as an indirect measure of the cell membrane integrity, function, and metabolism), the activity of phase I and II enzymes, and the evaluation of energy expenditure. Only one of the registered studies has been published at present. The results documented that the short-term consumption of $10 \mathrm{~g} /$ day of mustard (providing about $16 \mathrm{mg}$ of allyl-ITC) failed to affect energy expenditure and metabolic markers (i.e., plasma glucose, fatty acids) in a group of non-smoker individuals (44).

Most of the registered and published trials that were analyzed have investigated the effects of broccoli and broccoli sprout on different health status parameters. The few results available could suggest a possible beneficial effect against the inflammation as documented through the reduction of some markers such as IL-6 and C-reactive protein in smokers and in overweight 
subjects following the consumption of broccoli sprout. Only one study reported an attenuation in the expression of genes and associated oncogenic pathways of prostate cancer following a 4-week intervention with $300 \mathrm{~g}$ of GR-rich broccoli soup (11).

Concerning the impact on gut microbiota, the literature on GSLs is very recent, but it seems to suggest a strict relationship between the consumption of GSLs, their metabolism, and the composition of gut microbiota (73). In the present review, only two registered studies were focused on the impact of GSLs on gut microbiota composition. One study was performed on broccoli and not published yet (74), while another study was performed by administering a diet rich in Brassica vegetables (75). The latter already published (76), documented the capacity of a diet rich in Brassica vegetables (consisting of six portions of $84 \mathrm{~g}$ of broccoli, six portions of $84 \mathrm{~g}$ of cauliflower, and six portions of $300 \mathrm{~g}$ of a broccoli and sweet potato soup each week, for a period of 2 weeks) to increase human gut lactobacilli and to reduce the abundance of sulfate-reducing bacteria compared to a low Brassica vegetable-diet. However, no information on GSLs absorption and gut metabolism has been reported by the authors. Data from an in vitro study documented the formation of amines from the secondary degradation of ITCs following the incubation of human feces with GSLs (77), while another study showed the potential in vitro role of Bifidobacterium strains (belonging to the human intestinal microbiota) to metabolize GSLs into nitriles (25).

\section{Studies Performed on GSL-Rich Extracts/Pure Compounds}

As expected, we documented a rising trend of the last 10 years of studies performed on extracts or pure compounds despite only a few were those carried out on GSL-rich foods. This trend that is in favor of extracts and pure components, despite the difficulties in undertaking a human dietary intervention with a food product, probably derives from the growing interest of the pharmaceutical industry toward the potential use of GSLs, not only as food supplements but also as drugs. We have found that the research of the last years on GSL extracts was mainly focused on broccoli extracts and SFN (the main GSLmetabolite from broccoli). In this regard, several preclinical studies have been performed with the intention to reveal the mechanisms behind the protection against the development and/or progression of different diseases, particularly, cancer (78). The main putative protective mechanisms included the induction of endogenous antioxidants defense, detoxification enzymes, and the activation of cytoprotective genes $(70,79)$. Furthermore, in a recent review, it has been reported that SFN, indole-3-carbinol, and 3,3-diindolylmethane were the main GSL-metabolites showing a potential beneficial effect against diabetes, cancer, and neurodegenerative diseases (80). The biological effects observed were attributed to a plurality of molecular mechanisms acting simultaneously which included the modulation of xenobiotic metabolism, modulation of inflammation, regulation of apoptosis, cell cycle arrest, angiogenesis, and metastasis and regulation of epigenetic events $(80,81)$. The study of the potential health effects of SFN has a long-standing history showing its ability to act as an inducer of Nrf2. Several studies have also documented the ability of SFN to produce significant clinical responses in cancer and cognitive diseases (82-84). The main targets included the analysis of the expression of genes relevant for cellular protection and antioxidant activity such as Nrf2 in addition to epigenetic aspects such as the modulation of HDAC6 (82-84). These characteristics make SFN a potential candidate for the development of supplements and could explain its growing interest in the pharmacological research area. However, it should be underlined that most of the already published studies administered doses of ITCs from physiological to supraphysiological concentrations (range 100-600 $\mu \mathrm{mol}$ ). For example, Duran et al. (41) found an increase in SFN conjugate levels in plasma following in vivo supplementation for 3 days with $200 \mathrm{~g}$ of $\mathrm{BSH}$ compared to placebo, but the final concentration of metabolites was in the order of magnitude of nanomolar. In fact, the authors supposed that the minimal effects on antioxidant gene expression observed were probably due to insufficient plasma levels of SFN achieved. Furthermore, levels achieved in target tissues were likely less than those achieved in the plasma. In contrast, in another study, supplementation with $200 \mu \mathrm{mol}$ of SFN equivalents (from BSE) determined plasma levels of SFN metabolites at a magnitude of $\mu$ mol after $3 \mathrm{~h}$ and was able to elicit HDAC inhibitory responses in vivo (54). This discrepancy in the results obtained could be attributed to the different experimental designs in terms of extract administered, doses, and duration of intervention. Apart from the studies investigating the bioavailability of GSLs and their metabolites, the rest of the trials were focused on the role of the immune system, inflammatory response, cognitive function, cancer, and metabolic parameters (e.g., blood glucose). The results were not univocal and strictly dependent on the marker analyzed, site of measurement, dose administrated, and duration of the intervention. The preliminary findings obtained from human intervention studies have documented a possible beneficial effect from the consumption of broccoli sprout extract containing SFN (generally for doses close to $200 \mu \mathrm{mol}$ ) in the expression of genes related to cancer $(53,61)$ and in the modulation of markers of inflammation (51). However, due to the limited number of studies published, further investigations are mandatory before drawing any conclusion.

\section{Effect of Interindividual Response on GSLs Metabolism}

Another important aspect considered in the metabolism of GSLs is the impact of the genetic glutathione S-transferase (GST) polymorphisms that could affect interindividual response. For instance, Gasper et al. (85) demonstrated a relevant role of the GSTM1 allele in the metabolism of dietary ITCs. The authors found that GSTM1-null and GSTM1-positive subjects have different SFN metabolites concentrations in plasma and different rates of urinary excretion of SFN metabolites after broccoli consumption that could be explained by the GSTM genotype. These results were in line with the observations reported by other authors documenting a different GST activity and metabolism of GSLs $(86,87)$. Furthermore, numerous 
epidemiological studies associated GST polymorphisms with a different level of protection against oxidative stress other than an increased susceptibility to cancer diseases $(88,89)$. The study of the impact and/or contribution of GST polymorphic genes on GSLs bioavailability and/or health related outcomes has been considered only in two registered clinical trials but not published yet. One study aimed to investigate the impact of broccoli consumption ( $400 \mathrm{~g}$ of the high GSLs broccoli each week for 12 weeks) on CVD risk by considering the potential contribution of the different polymorphisms (GSTM1, GSTT1, and GSTP1) (90). The second study aimed to determine the possible differential effects of the GSTM1 genotype, GSTT1 genotype, and their combined effects on PEITC-NNK association on the metabolism and excretion of PEITC (91). The results will be useful to provide more data on the potential impact and/or contribution of GST polymorphisms and genotypes on the capacity to differently metabolize GSLs. In addition, the results obtained on CVD risk will be pivotal for further research on this relatively new Research Topic.

\section{Current Limitations and Gaps of the Research}

Overall, the main limitations and criticisms that emerged from the analysis of the studies include the following: (1) a lower number of subjects were enrolled and their heterogeneous characteristics, (2) the high variability of the individual response, (3) the poor quality of the study design adopted (e.g., some studies lack a control group), (4) the amount of food administered that in some cases resulted below the threshold reported in epidemiological studies and in some cases the amount of extracts and/or single compounds provided that was above to the dose achievable through the diet, and (5) the lack of validated biomarkers. In this regard, a strong gap of the research remains the validation of appropriate biomarkers directly linked to the endpoint and able to be affected following a dietary intervention.

A further gap is insufficient information related to the absorption and metabolism of GSLs and their metabolites from single and different food sources. This could be partially attributed to the complex metabolism and/or to the absence of standards and methodologies for the identification of the compounds. Since GSLs are extensively metabolized, the identification of more specific dietary biomarkers able to trace their metabolism represents a challenging achievement. Another important gap that should be addressed is the study of the potential interaction among different GSLs and the interaction between GSLs with other dietary components present in the brassica or in the whole diet. In fact, it is important to point out that food should be tested in its pattern of consumption within a context of a balanced, adequate, and varied diet in which the contribution of the single food or food component should be considered. In this regard, many dietary and non-dietary factors could positively or negatively influence the digestion and absorption of GSLs/GSL-metabolites, their excretion, and tissue distribution. Furthermore, it cannot be excluded a possible additive or synergistic or antagonist effect when GSLs are administered together with other dietary or non-dietary factors. Another relevant point is that the lack of exhaustive information is related to the degradation rate of GSLs during food processing and the potential impact of their bioavailability. Despite numerous studies performed, a major effort should be directed on this topic by combining, for example, the use of predictive models able to study such phenomena and capable to predict the bioavailability in vivo. In addition, the impact of age, sex, microbiome composition, and genetic polymorphisms on absorption, distribution, metabolism, and excretion of GSLs should be deeply investigated. In part, this aspect has been already analyzed within the POSITIVE project also for GSLs (92). However, the study of the individual response is crucial for a clear understanding of the impact of GSLs and derivatives on human health.

\section{Strength and Limitations of the Revision}

Overall, the following review presents several strengths and limitations. One strength is the capacity to provide a prompt and updated list of clinical trials performed on GSLs including those that are not yet published. Additionally, the registered studies can provide information that is often missing such as specific details on the characteristics of the study population, study design, and all outcomes measured. On the other hand, several limitations can be remarked. For example, a relevant limit is represented by the incomplete real overview of the number of studies performed on GSLs and GSL-rich foods due to the lack of their registration in a public registry. This problem is tangible particularly for the studies performed in the past since registration was not considered common practice. Another important limitation is the lack of information related to the results of the studies. Most of them are very recent and not already published, and this does not allow to have a clear overview of all the results.

\section{CONCLUSIONS AND FUTURE DIRECTIONS}

In conclusion, GSLs and GSL-rich foods have attracted great interest in the research field of dietary bioactives. Most of the human intervention studies were performed on SFN and broccoli. Apart from the study of GSLs metabolism, other Research Topics included cancer, oxidative stress, and inflammation. The results available remain conflicting and further effort should be done to clarify the role of pure/extracts and foods on these matters. However, new Research Topics have been developed including the study of gut microbiota and its contribution to GSLs metabolism, and the impact of GSLs and GSL-rich foods on skin health and cognitive function. It seems important that future research consider the contribution of the single components and/or foods, the doses administered, and, above all, the individual response in terms of gut microbiota and genetic polymorphisms that significantly affect the absorption, along with the metabolism of GSLs. For this purpose, the development of dietary intervention studies is highly recommended by taking into consideration also the doseresponse behavior and the mechanisms of interaction between 
the GSLs/GSL-metabolites and their target tissues. For this latter point, the use of validated biomarkers is mandatory. It would be also interesting to enlarge the research to different and less common food sources of GSLs (e.g., kale, rocket salad, and mustard) since they are distinctive of peculiar secondary GSL metabolites whose potential bioactivity has not been evaluated yet. Moreover, the increased knowledge on the contribution of the different classes and types of vegetables in terms of bioactive compounds and the evaluation of their modulatory role represents an important aspect in the context of a plantbased diet.

\section{AUTHOR CONTRIBUTIONS}

MM and CDB conducted the literature search and reviewed the studies selected. DM served as the third reviewer. MM, SV, and MT prepared the tables and figures. MM, DM, and CDB were involved in the protocol design, data analyses, and drafted the manuscript. PR and MP critically revised the scientific content and improved the quality of the manuscript. All authors contributed to the article and approved the submitted version.

\section{REFERENCES}

1. Pal Vig A, Rampal G, Singh Thind T, Arora S. Bio-protective effects of glucosinolates - a review. Food Sci Tech. (2009) 42:1561-72. doi: 10.1016/j.lwt.2009.05.023

2. Barba FJ, Nikmaram N, Roohinejad S, Khelfa A, Zhu Z, Koubaa M. Bioavailability of glucosinolates and their breakdown products: impact of processing. Front Nutr. (2016) 3:24. doi: 10.3389/fnut.2016.00024

3. Nguyen VPT, Stewart J, Lopez M, Ioannou I, Allais F. Glucosinolates: natural occurrence, biosynthesis, accessibility, isolation, structures, and biological activities. Molecules. (2020) 25:4537. doi: 10.3390/molecules 25194537

4. Agerbirk N, Olsen CE. Glucosinolate structures in evolution. Phytochemistry. (2012) 96:16-45. doi: 10.1016/j.phytochem.2012.02.005

5. Fahey JW, Zalcmann AT, Talalay P. The chemical diversity and distribution of glucosinolates and isothiocyanates among plants. Phytochemistry. (2001) 56:5-51. doi: 10.1016/S0031-9422(00)00316-2

6. Bones AM, Rossiter JT. The enzymic and chemically induced decomposition of glucosinolates. Phytochemistry. (2006) 67:105367. doi: 10.1016/j.phytochem.2006.02.024

7. Winde I, Wittstoc U. Insect herbivore counteradaptations to the plant glucosinolate-myrosinase system. Phytochemistry. (2011) 72:1566-75. doi: 10.1016/j.phytochem.2011.01.016

8. Palermo M, Pellegrini N, Fogliano V. The effect of cooking on the phytochemical content of vegetables. J Sc Food Agric. (2013) 94:105770. doi: 10.1002/jsfa.6478

9. Riso P, Brusamolino A, Moro M, Porrini M. Absorption of bioactive compounds from steamed broccoli and their effect on plasma glutathione S-transferase activity. Int J Food Sci Nutr. (2009) 60(Suppl. 1):5671. doi: 10.1080/09637480802089751

10. Tran HTT, Schreiner M, Schlotz N, Lamy E. Short-term dietary intervention with cooked but not raw brassica leafy vegetables increases telomerase activity in CD8+ lymphocytes in a randomized human trial. Nutrients. (2019) 1:786. doi: 10.3390/nu11040786

11. Traka MH, Melchini A, Coode-Bate J, Al Kadhi O, Saha S, Defernez M, et al. Transcriptional changes in prostate of men on active surveillance after a 12-mo glucoraphanin-rich broccoli intervention-results from the Effect of Sulforaphane on prostate CAncer PrEvention (ESCAPE) randomized controlled trial. Am J Clin Nutr. (2019) 109:1133-44. doi: 10.1093/ajcn/nqz012

\section{FUNDING}

This research is part of the project MIND FoodS HUB (Milano Innovation District Food System Hub): Innovative concept for the eco-intensification of agricultural production and for the promotion of dietary patterns for human health and longevity through the creation in MIND of a digital Food System Hub, cofunded by POR FESR 2014-2020_BANDO Call HUB Ricerca e Innovazione, Regione Lombardia. Open access publication fees will be provided by Piano di sostegno alla ricerca- Linea 2, azione A-Grant Nos. PSR2020-CDELB.

\section{ACKNOWLEDGMENTS}

PR, DM, and CDB acknowledge the SYSTEMIC project (ERAHDHL Knowledge Hub on Food and Nutrition Security) with national funding support provided by Mipaaf (MIMOSA project, DG DISR-DISR 04-Prot. Uscita N.0041532, 23/12/2019). PR and $\mathrm{CDB}$ also are grateful to the European Cooperation for Science and Technology (COST Action) CA16112 NutRedOx: Personalized Nutrition in Aging Society: Redox Control of Major Age-related Diseases.

12. Riso P, Martini D, Visioli F, Martinetti A, Porrini M. Effect of broccoli intake on markers related to oxidative stress and cancer risk in healthy smokers and nonsmokers. Nutr Cancer. (2009) 61:232-7. doi: 10.1080/01635580802425688

13. Riso P, Vendrame S, Del Bo' C, Martini D, Martinetti A, Seregni E, et al. Effect of 10-day broccoli consumption on inflammatory status of young healthy smokers. Int J Food Sci Nutr. (2014) 65:106-11. doi: 10.3109/09637486.2013.830084

14. Angelino D, Dosz EB, Sun J, Hoeflinger JL, Van Tassell ML, Chen P, et al. Myrosinase-dependent and -independent formation and control of isothiocyanate products of glucosinolate hydrolysis. Front Plant Sci. (2015) 6:831. doi: 10.3389/fpls.2015.00831

15. Egner PA, Chen JG, Zarth AT, Ng DK, Wang JB, Kensler KH, et al. Rapid and sustainable detoxication of airborne pollutants by broccoli sprout beverage: results of a randomized clinical trial in China. Cancer Prev Res. (2014) 7:813-23. doi: 10.1158/1940-6207.CAPR-14-0103

16. Riso P, Del Bo' C, Vendrame S, Brusamolino A, Martini D, Bonacina G, et al. Modulation of plasma antioxidant levels, glutathione S-transferase activity and DNA damage in smokers following a single portion of broccoli: a pilot study. J Sci Food Agric. (2014) 94:522-8. doi: 10.1002/jsfa.6283

17. Sivapalan T, Melchini A, Saha S, Needs PW, Traka MH, Tapp $\mathrm{H}$, et al. Bioavailability of glucoraphanin and sulforaphane from high-glucoraphanin broccoli. Mol Nutr Food Res. (2018) 62:e1700911. doi: 10.1002/mnfr.201700911

18. Riso P, Martini D, Møller P, Loft S, Bonacina G, Moro M, et al. DNA damage and repair activity after broccoli intake in young healthy smokers. Mutagenesis. (2010) 25:595-602. doi: 10.1093/mutage/geq045

19. Holst B, Williamson G. A critical review of the bioavailability of glucosinolates and related compounds. Nat Prod Rep. (2004) 21:42547. doi: 10.1039/b204039p

20. Getahun SM, Chung FL. Conversion of glucosinolates to isothiocyanates in humans after ingestion of cooked watercress. Cancer Epidemiol Biomarkers Prev. (1999) 8:447-51.

21. Conaway CC, Getahun SM, Liebes LL, Pusateri DJ, Topham DK, BoteroOmary $\mathrm{M}$, et al. Disposition of glucosinolates and sulforaphane in humans after ingestion of steamed and fresh broccoli. Nutr Cancer. (2000) 38:16878. doi: 10.1207/S15327914NC382_5

22. Rouzaud G, Young SA, Duncan AJ. Hydrolysis of glucosinolates to isothiocyanates after ingestion of raw or microwaved cabbage 
by human volunteers. Cancer Epidemiol Biomarkers Prev. (2004) 13:125-31. doi: 10.1158/1055-9965.EPI-085-3

23. Bheemreddy RM, Jeffery EH. The metabolic fate of purified glucoraphanin in F344 rats. J Agric Food Chem. (2007) 55:2861-6. doi: 10.1021/jf0633544

24. Bollard M, Stribbling S, Mitchell S, Caldwell J. The disposition of allyl isothiocyanate in the rat and mouse. Food Chem Toxicol. (1997) 35:93343. doi: 10.1016/S0278-6915(97)00103-8

25. Cheng DL, Hashimoto K, Uda Y. In vitro digestion of sinigrin and glucotropaeolin by single strains of Bifidobacterium and identification of the digestive products. Food Chem Toxicol. (2004) 42:351-7. doi: 10.1016/j.fct.2003.09.008

26. van Poppel G, Verhoeven DT, Verhagen H, Goldbohm RA. Brassica vegetables and cancer prevention. Epidemiology and mechanisms. Adv Exp Med Biol. (1999) 472:159-68. doi: 10.1007/978-1-4757-3230-6_14

27. Liu $\mathrm{X}, \mathrm{Lv} \mathrm{K}$. Cruciferous vegetables intake is inversely associated with risk of breast cancer: a meta-analysis. Breast. (2013) 22:30913. doi: 10.1016/j.breast.2012.07.013

28. Verhoeven DT, Goldbohm RA, van Poppel G, Verhagen H, van den Brandt PA. Epidemiological studies on brassica vegetables and cancer risk. Cancer Epidemiol Biomarkers Prev. (1996) 5:733-48.

29. Colditz GA, Branch LG, Lipnick RJ, Willett WC, Rosner B, Posner BM, et al. Increased green and yellow vegetable intake and lowered cancer deaths in an elderly population. Am J Clin Nutr. (1985) 41:32-6. doi: 10.1093/ajcn/41.1.32

30. Chyou PH, Nomura AM, Hankin JH, Stemmermann GN. A case-cohort study of diet and stomach cancer. Cancer Res. (1990) 50:7501-4.

31. Gao C, Tajima K, Kuroishi T, Hirose K, Inoue M. Protective effects of raw vegetables and fruit against lung cancer among smokers and ex-smokers: a case-control study in the Tokai Area of Japan. Jpn J Cancer Res. (1993) 84:594-600. doi: 10.1111/j.1349-7006.1993.tb02018.x

32. La Vecchia C, Negri E, Decarli A, D'Avanzo B, Franceschi S. A case-control study of diet and gastric cancer in Northern Italy. Hum Cancer. (1987) 40:484-9. doi: 10.1002/ijc.2910400409

33. La Vecchia C, Negri E, Decarli A, D’Avanzo B, Gallotti L, Gentile A, et al. A case-control study of diet and colo-rectal cancer in Northern Italy. Hum Cancer. (1988) 41:492-8. doi: 10.1002/ijc.2910410404

34. ClinicalTrials Registry. Available online at: https://clinicaltrials.gov (accessed April 30, 2021).

35. ISRCTN Registry. Available online at: https://www.isrctn.com (accessed April $30,2021)$.

36. Marino M, Del Bo' C, Martini D, Porrini M, Riso P. A review of registered clinical trials on dietary (poly)phenols: past efforts and possible future direction. Foods. (2020) 9:1606. doi: 10.3390/foods9111606

37. Christiansen B, Muguerza NB, Petersen AM, Kveiborg B, Madsen R, Thomas $\mathrm{H}$, et al. Ingestion of broccoli sprouts does not improve endothelial function in humans with hypertension. PLOS ONE. (2010) 5:e12461. doi: 10.1371/journal.pone.0012461

38. Armah CN, Traka MH, Dainty JR, Defernez M, Janssens A, Leung W, et al. A diet rich in high-glucoraphanin broccoli interacts wih genotype to reduce discordance in plasma metabolite profiles by modulating mitochondrial function. Am J Clin Nutr. (2013) 98:712-22. doi: 10.3945/ajcn.113.0 65235

39. Noah TL, Zhang H, Zhou H, Glista-Baker E, Müller L, Bauer RN, et al. Effect of broccoli sprouts on nasal response to live attenuated influenza virus in smokers: a randomized, double-blind study. PLoS ONE. (2014) 9:e98671. doi: 10.1371/journal.pone.0098671

40. Doss JF, Jonassaint JC, Garrett ME, Ashley-Koch AE, Telen MJ, Chi J. Phase 2 study of a sulforaphane-containing broccoli sprout homogenate for sickle cell disease. PLoS ONE. (2016) 11:e0152895. doi: 10.1371/journal.pone.0152895

41. Duran CG, Burbank AJ, Mills KH, Duckworth HR, Aleman MM, Keisc MJ, et al. A proof-of-concept clinical study examining the NRF2 activator sulforaphane against neutrophilic airway inflammation. Resp Res. (2016) 17:89. doi: 10.1186/s12931-016-0406-8

42. Müller L, Meyer M, Bauer RN, Zhou H, Zhang H, Jones S, et al. Effect of broccoli sprouts and live attenuated influenza virus on peripheral blood natural killer cells: a randomized. PLoS One. (2016) 11:e0147742. doi: 10.1371/journal.pone.0147742

43. Sudini K, Diette GB, Breysse PN, McCormack MC, Bull D, Biswal S, et al. A randomized controlled trial of the effect of broccoli sprouts on anti-oxidant gene expression and airway inflammation in asthmatics. J All Cl Imm Pract. (2016) 4:932-40. doi: 10.1016/j.jaip.2016.03.012

44. Langeveld M, Tan CY, Soeters MR, Virtue S, Watson LPE, Murgatroyd PR, et al. No metabolic effects of mustard allylisothocyanate compared with placebo in man. Am J Clin Nutr. (2017) 106:1197-205. doi: 10.3945/ajcn.116.148395

45. Nguyen BAV, McDonald G, Fiorentino F, Reeves BC, Kwak J, Pyo $\mathrm{S}$, et al. Consumption of broccoli sprouts attenuates intracellular P38 kinase and reactive oxygen species pro-inflammatory activation in human leukocytes: a randomised-controlled trial. J Clin Nutr Diet. (2017) 3:25. doi: 10.4172/2472-1921.100060

46. Charron CS, Vinyard BT, Jeffery EH, Ross SA, Seifried HE, Novotny JA. BMI is associated with increased plasma and urine appearance of glucosinolate metabolites after consumption of cooked broccoli. Front Nutr. (2020) 7:575092. doi: 10.3389/fnut.2020.575092

47. López-Chillón MT, Carazo-Díaz C, Prieto-Merino D, Zafrilla P, Moreno DA, Villaño D. Effects of long-term consumption of broccoli sprouts on inflammatory markers in overweight subjects. Clin Nutr. (2019) 38:74552. doi: 10.1016/j.clnu.2018.03.006

48. Chen J, Johnson J, Egner P, Ng D, Zhu J, Wang J, et al. Dose-dependent detoxication of the airborne pollutant benzene in a randomized trial of broccoli sprout beverage in Qidong, China. Am J Clin Nutr. (2019) 110:67584. doi: $10.1093 /$ ajcn/nqz122

49. Coode-Bate J, Sivapalan T, Melchini A, Saha S, Needs PW, Dainty JR, et al. Accumulation of dietary s-methyl cysteine sulfoxide in human prostate tissue. Mol.Nutr Food Res. (2019) 63:1900461. doi: 10.1002/mnfr.201900461

50. Poulton EJ, Levy L, Lampe JW, Shen DD, Tracy J, Shuhart MC, et al. Sulforaphane is not an effective antagonist of the human pregnane X-receptor in vivo. Toxicol Appl Pharmacol. (2013) 266:122-31. doi: 10.1016/j.taap.2012.10.029

51. Heber D, Li Z, Garcia-Lloret M, Wong AM, Lee TA, Thames G, et al. Sulforaphane-rich broccoli sprout extract attenuates nasal allergic response to diesel exhaust particles. Food Funct. (2014) 5:35-41. doi: 10.1039/C3FO60277J

52. Singh K, Connors SL, Macklin EA, Smith KD, Fahey JW, Talalay P, et al. Sulforaphane treatment of autism spectrum diorder (ASD). Proc Natl Acad Sci USA. (2014) 111:43. doi: 10.1073/pnas.1416940111

53. Atwell LL, Zhang Z, Mori M, Farris P, Vetto JT, Naik AM, et al. Sulforaphane bioavailability and chemopreventive activity in women scheduled for breast biopsy. Cancer Prev Res. (2015) 8:1184-91. doi: 10.1158/1940-6207.CAPR-15-0119

54. Rajendran P, Dashwood W, Li L, Kang Y, Kim E, Johnson G, et al. Nrf2 status affects tumor growht, HDAC3 gene promoter associations, and the response to sulforaphane in the colon. Clin Epigenet. (2015) 7:102. doi: 10.1186/s13148-015-0132-y

55. Shiina A, Kanahara N, Sasaki T, Oda Y, Hashimoto T, Hasegawa T, et al. An open study of sulforaphane-rich broccoli sprout extract in patients with schizophrenia. Clin Psychopharmacol Neurosci. (2015) 13:62-7. doi: 10.9758/cpn.2015.13.1.62

56. Yuan J, Stepanov I, Murphy SE, Wang R, Allen S, Jensen S, et al. Clinical trial of 2-phenethyl isothiocyanate as an inhibitor of metabolic activation of a tobacco-specific lung carcinogen in cigarette smokers. Cancer Prev Res (Phila). (2016) 9:396-405. doi: 10.1158/1940-6207.CAPR-15-0380

57. Wise RA, Holbrook JT, Criner G, Sethi S, Rayapudi S, Sudini KR, et al. Lack of effect of oral sulforaphane administration on Nrf2 expression in COPD: a randomized, double-blind, placebo controlled trial. PLOS ONE. (2016) 11:e0163716. doi: 10.1371/journal.pone.0163716

58. Axelsson AS, Tubbs E, Mecham B, Chacko S, Nenonen HA, Tang Y, et al. Sulforaphane reduces hepatic glucose production and improve glucose control in patients with type 2 diabetes. Sci Transl Med. (2017) 9:eaah4477. doi: 10.1126/scitranslmed.aah4477

59. Bent S, Lawton B, Warren T, Widjaja F, Dang K, Fahey JW, et al. Identification of urinary metabolites that correlate with clinical improvements in children with autism treated with sulforaphane from broccoli. Mol Autism. (2018) 9:35. doi: 10.1186/s13229-018-0218-4

60. Liu H, Zimmerman AW, Singh K, Connors SL, Diggins E, Stephenson KK, et al. Biomarker exploration in human peripheral blood mononuclear cells for monitoring sulforaphane treatment responses in autism spectrum disorder. Sci Rep. (2020) 10:5822. doi: 10.1038/s41598-020-62714-4 
61. Zhang Z, Garzotto M, Davis II EW, Mori M, Stoller WA, Farris PE, et al. Sulforaphane bioavailability and chemopreventive activity in men presenting for biopsy of the prostate gland: a randomized controlled trial. Nutr Cancer. (2020) 72:74-87. doi: 10.1080/01635581.2019.1619783

62. Wu QJ, Yang Y, Vogtmann E, Wang J, Han LH, Li HL, et al. Cruciferous vegetables intake and the risk of colorectal cancer: a meta-analysis of observational studies. Ann Oncol. (2013) 24:107987. doi: 10.1093/annonc/mds601

63. Kristal AR, Lampe JW. Brassica vegetables and prostate cancer risk: a review of the epidemiological evidence. Nutr Cancer. (2009) 42:19. doi: 10.1207/S15327914NC421_1

64. Metabolic Effects of Mustard. Available online at: https://www.isrctn.com/ ISRCTN19147515?q=19147515\&filters $=\&$ sort $=\&$ offset $=1$ \&totalResults $=1 \&$ page $=1 \&$ pageSize $=10 \&$ searchType $=$ basic - search $($ accessed April 30, 2021).

65. Effect of Kale Consumption on Human Xenobiotic Metabolizing Enzymes. Available online at: https://clinicaltrials.gov/ct2/show/NCT03449849 (accessed April 30, 2021).

66. Glucobrassicin-Brussel Sprout Effect on D10 Phe Metabolism. Available online at: https://clinicaltrials.gov/ct2/show/NCT02999399 (accessed April 30, 2021).

67. Does Watercress Intake Have an Impact on Cancer Patients Outcomes: a Longitudinal Trial. Available online at: https://clinicaltrials.gov/ct2/show/ NCT02468882 (accessed April 30, 2021).

68. A Study of the Effects of PEITC on Oral Cells With Mutant p53. Available online at: https://clinicaltrials.gov/ct2/show/NCT01790204 (accessed April 30, 2021).

69. Green Vegetables and Women's Health. Available online at: https:// clinicaltrials.gov/ct2/show/NCT01726127 (accessed April 30, 2021).

70. Kapusta-Duch J, Kopeć A, Piatkowska E, Borczak B, Leszczyńska T. The beneficial effects of Brassica vegetables on human health. Rocz Panstw Zakl Hig. (2012) 63:389-95.

71. Kokhdan EP, Khodabandehloo H, Ghahremani H, Doustimotlagh AH. A narrative review on therapeutic potentials of Watercress in human disorders. Evid Based Complement Altern Med. (2021) 2021:5516450. doi: 10.1155/2021/5516450

72. Bahadoran Z, Mirmiran P, Azizi F. Potential efficacy of broccoli sprouts as a unique supplement for management of type 2 diabetes and its complications. J Med Food. (2013) 16:375-82. doi: 10.1089/jmf.2012.2559

73. Dingeo G, Brito A, Samouda H, Iddir M, La Frano MR, Bohn T. Phytochemicals as modifiers of gut microbial communities. Food Funct. (2020) 11:8444. doi: 10.1039/D0FO01483D

74. Discovery of Biological Signatures for Cruciferous Vegetable Intake (Single Serving). Available online at: https://clinicaltrials.gov/ct2/show/ NCT04641026 (accessed April 30, 2021).

75. Effects of Brassica on Human Gut Lactobacilli (EBL). Available online at: https://clinicaltrials.gov/ct2/show/NCT02291328 (accessed April 30, 2021).

76. Kellingray L, Tapp HS, Saha S, Doleman JF, Narbad A, Mithen RF. Consumption of a diet rich in Brassica vegetables is associated with a reduced abundance of sulphate-reducing bacteria: a randomized crossover study. $\mathrm{Mol}$ Nutr Food Res. (2017) 61:1600992 doi: 10.1002/mnfr.201600992

77. Combourieu B, Elfoul L, Delort AM, Rabot S. Identification of new derivatives of sinigrin and glucotropaeolin produced by the human digestive microflora using $1 \mathrm{H}$ NMR spectroscopy analysis of in vitro incubations. Drug Metab Dispos. (2001) 29:1440-5.

78. Banerjee S, Paruthy SB. Therapeutic paradigm underscoring glucosinolate sulforaphane in chemo- and radiosensitization of cancer: preclinical and clinical perspective. In: eds Mérillon JM, Ramawat K, editors. Glucosinolates. Reference Series in Phytochemistry. Cham: Springer (2017). p.339-79. doi: 10.1007/978-3-319-25462-3_19

79. Molina-Vargas LF. Mechanism of action of isothiocyanates. A review. Agron Colomb. (2013) 31:68-75.
80. Capuano E, Dekker M, Verkerk R, Oliviero T. Food as pharma? The case of glucosinolates. Curr Pharm Des. (2017) 23:269721. doi: 10.2174/1381612823666170120160832

81. Riso P, Del Bo' C, Vendrame S. Preventive effects of broccoli bioactives. In: Cancer. (2014). p. 115-26. doi: 10.1016/b978-0-12-405205-5.00011-8

82. Klaunig JE. Oxidative stress and cancer. Curr Pharm Des. (2018) 24:47718. doi: 10.2174/1381612825666190215121712

83. Li T, Zhang C, Hassan S, Liu X, Song F, Cheng K, et al. Histone deacetylase 6 in cancer. J Hematol Oncol. (2018) 11:111. doi: 10.1186/s13045-0180654-9

84. Brandes MS, Gray NE. NRF2 as a therapeutic target in neurodegenerative diseases. ASN Neuro. (2020) 12:1-23. doi: 10.1177/1759091419899782

85. Gasper AV, Al-janobi A, Smith JA, Bacon JR, Fortun P, Atherton C, et al. Glutathione S-transferase M1 polymorphism and metabolism of sulforaphane from standard and high-glucosinolate broccoli. Am J Clin Nutr. (2005) 82:1283-91. doi: 10.1093/ajcn/82.6.1283

86. Steck SE, Gammon MD, Herbert JR, Wall DE, Zeisel SH. GSTM1, GSTT1, GSTP1, and GSTA1 polymorphisms and urinary isothiocyanate metabolites following broccoli consumption in humans. J Nutr. (2007) 137:9049. doi: $10.1093 / \mathrm{jn} / 137.4 .904$

87. Takeda GK, Leite DB, Juanqueira MG, Lopes LAF, da Silva IDCG, Baracat FF. Assessment of glutthione S-transferaseM1 (GSTM1) and its polymorphisms GSTM1 null in the reponse to treatment with chemotherapy in advanced ovarian carcinoma. Einstein. (2011) 9:36771. doi: 10.1590/s1679-45082011ao1872

88. Joseph MA, Moysich KB, Freudenheim JL, Shields PG, Bowman ED, Zhang $\mathrm{Y}$, et al. Cruciferous vegetables, genetic polymorphisms in glutathione Stransferases M1 and T1, and prostate cancer risk. Nutr Cancer. (2004) 50:20613. doi: 10.1207/s15327914nc5002_11

89. Spitz MR, Duphorne CM, Detry MA, Pillow PC, Amos CI, Lei L, et al. Dietary intake of isothiocyanates: evidence of a joint effect with glutathione S-transferase polymorphisms in lung cancer risk. Cancer Epidem Biomar. (2000) 9:1017-20.

90. Diet and Vascular Health Study (BROCCOLI). Available online at: https:// clinicaltrials.gov/ct2/show/NCT01114399 (accessed on 30 April 2021)

91. Phenethyl Isothiocyanate in Preventing Lung Cancer in Smokers. Available online: https://clinicaltrials.gov/ct2/show/NCT00691132 (accessed April 30, 2021).

92. Morand C, De Roos B, Garcia-Conesa MT, Gibney ER, Landberg R, Manach $\mathrm{C}$, et al. Why interindividual variation in response to consumption of plant food bioactives matters for future personalised nutrition. Proc Nutr Soc. (2020) 79:225-35. doi: 10.1017/S0029665120000014

Conflict of Interest: The authors declare that the research was conducted in the absence of any commercial or financial relationships that could be construed as a potential conflict of interest.

Publisher's Note: All claims expressed in this article are solely those of the authors and do not necessarily represent those of their affiliated organizations, or those of the publisher, the editors and the reviewers. Any product that may be evaluated in this article, or claim that may be made by its manufacturer, is not guaranteed or endorsed by the publisher.

Copyright (C) 2021 Marino, Martini, Venturi, Tucci, Porrini, Riso and Del Bo'. This is an open-access article distributed under the terms of the Creative Commons Attribution License (CC BY). The use, distribution or reproduction in other forums is permitted, provided the original author(s) and the copyright owner(s) are credited and that the original publication in this journal is cited, in accordance with accepted academic practice. No use, distribution or reproduction is permitted which does not comply with these terms. 